\title{
INTERNATIONAL DISPERSION AND PROFITABILITY: AN INSTITUTION-BASED APPROACH
}

This study examines the effect of international dispersion on profitability. We use an institution-based approach to propose that increases in international dispersion lead, on average, to profitability downturns. We also argue that this liability of foreignness will affect multinationals from infrastructure industries to a lesser extent because in these industries: 1) the importance of cultural fit in products is low; 2) firms possess regulatory expertise; and 3) firms have limited aggregation opportunities at the regional level. We test our hypotheses on a panel of Spanish listed firms (1986-2007). Our findings point to a negative linear relationship between international dispersion and profitability, which is flatter for infrastructure multinationals. These results contribute to a more context-based understanding of internationalization that highlights the shortcomings of establishing a dispersed international footprint.

Keywords: Internationalization; profitability; liability of foreignness; regionalization; institution-based view; infrastructure firms.

\section{Introduction}

Assessing the performance consequences of multinationality is a key topic in the International Business (IB) literature (see Nguyen 2017 for a recent review). However, there are still "more questions than answers" (Glaum and Oesterle 2007). Firms that venture beyond domestic borders can capitalize on their firm-specific assets (e.g. Buckley and Casson 1976; Caves 1971; Goerzen and Beamish 2003); access new resources (Benito 2015; Cuervo-Cazurra et al. 2015); achieve economies of scale and scope (e.g. Contractor et al. 2003; Hennart 2007; Miller et al. 2016; Tallman and Li 1996); and exploit arbitrage opportunities (Allen and Pantzalis 1996; Ghemawat 2007; Kogut 1985). Nonetheless, the profitability of multinational firms can be seriously compromised by the so-called liability of foreignness (LoF); that is, the additional costs in which multinationals incur because of the disadvantageous position that they hold in host markets compared to domestic incumbents (Hymer 1976; Zaheer 1995).

The literature on the LoF has acknowledged its multifaceted nature (Cuervo-Cazurra et al. 2007; Eden and Miller 2001). As such, some scholars have tried to refine our understanding of the concept by unpacking its triggers. For instance, Eden and Miller (2004) argue that the LoF arises from the unfamiliarity, relational and discriminatory hazards that multinationals are bound to face in foreign countries due to factors such as cultural and regulatory differences. Rugman and Verbeke (2007) go one step further and claim that costs of operating abroad are even higher when multinationals expand to another region, giving rise to the liability of interregional foreignness (LoIF). This additional obstacle may be the reason why some multinationals prefer to constrain their geographic reach to their home region at the expense of achieving global benefits, as the regionalization literature suggests (e.g. Oh and Li 2015; Rugman and Verbeke 2004). However, a clear-cut distinction among regions obviates the potential coexistence of similarities and differences within and across them (Dunning et al. 2007). Integrating the different conceptualizations of the LoF, Asmussen and Goerzen (2013) identified three different ramifications: cultural, institutional, and regional. They argued that the main costs that multinationals face when expanding abroad vary according to the dispersion of their locations across cultures, institutional settings, and regions. However, a comparative analysis of the impact of each of these dimensions of international dispersion on firm profitability has not been carried out so far.

We contribute to fill this gap not only by analyzing how each of these dimensions affects firm profitability, but also by examining the extent to which cross-industry differences moderate these relationships. Zhou and Guillén (2016) found that firms choose the type of foreign direct investments 
(FDI) that they undertake based on different country distance dimensions to minimize the impact of the LoF. This result suggests that some heterogeneity might exist in the relationship between the LoF and profitability at the firm or industry levels. Therefore, new research on the topic should determine the circumstances under which firms and/or industries may be less affected by the LoF. For this reason, we aim to answer the following research question: how does international dispersion affect the profitability of infrastructure firms ${ }^{1}$ compared to that of their non-infrastructure counterparts? Although previous studies propose that infrastructure firms have an ability to navigate through different institutional contexts (Bonardi 2004; Guillén and García-Canal 2010; Henisz 2003), the performance implications of their internationalization decisions have not been analyzed yet. We claim that these industries are less affected by the cultural, regulatory and regional dimensions of the LoF because for them 1) the importance of cultural fit in products is low; 2) their regulatory expertise facilitates navigating through different regulatory environments; and 3) there are limited aggregation opportunities at the regional level. We explain each of these points in more detail in subsequent sections.

Adopting an institution-based view angle (e.g. Peng 2002; Peng et al. 2008; Peng et al. 2009), we hypothesize that the profitability of multinationals decreases, on average, as their operations become more internationally dispersed. We also expect this relationship to be flatter for infrastructure multinationals. We test our hypotheses on a panel-data sample of Spanish listed firms (1986-2007). Our results reveal that higher degrees of international dispersion diminish profitability. By contrast, operating in infrastructure industries buffers the negative consequences of that higher dispersion, thus validating the arguments in favor of a flatter relationship between both variables. In fact, our findings show that infrastructure multinationals are even able to profit from venturing outside the boundaries of their home region. Therefore, it seems that these multinationals are better prepared to operate in different countries and regions.

We add to the existing literature in a variety of ways. First, we shed more light on the relationship between internationalization and performance by analyzing the multifaceted impact of the LoF on profitability. Second, we extend the institution-based view to make an initial attempt at empirically testing the factors that make some multinationals better able to mitigate the negative effects of managing their international footprint across borders. We do so by focusing on the different profitability consequences of international dispersion in infrastructure and non-infrastructure multinationals. This also responds to the call for a more context-based understanding of the outcomes of internationalization (e.g. Bausch and Krist 2007; Kim et al. 2015). Finally, our results add to the regionalization debate by confirming that we currently live in a semi-globalized world where regional borders still matter for most firms (Flores et al. 2013; Ghemawat 2003, 2005, 2007; Kim and Aguilera 2015; Rugman and Verbeke 2004, 2007).

Our findings carry important implications for managers, governments and policymakers. Despite the largely shared perception that multinationals should follow global strategies to pursue global opportunities (Verbeke and Asmussen 2016), managers should be aware that there is still a long way ahead for multinationals to fully profit from scattering their operations across different national and regional contexts even if it is true that some multinationals are in a better position to achieve it. Actually, multinationals are starting to display a higher caution in their foreign expansion. What The Economist calls "the retreat of the global company" is just a reaction of many multinational companies to the high

\footnotetext{
${ }^{1}$ Based on Fernández-Méndez et al. (2015), we define infrastructure firms as those operating in electricity, water, oil, gas, transportation, telecommunications, and construction.

${ }^{2}$ Phrase used by The Economist to title an article on this topic (The retreat of the global company), published on 28 January 2017.
} 
costs of operating at a global scale, and should challenge governments and policymakers to rethink their attitude towards FDI.

\section{Conceptual Background}

The literature on internationalization and performance — commonly measured as profitability — has drawn the attention of numerous scholars throughout the years. Early studies focused mostly on examining the relationship between degree of internationalization and profitability, albeit with inconclusive results (see Nguyen 2017 for a recent review). ${ }^{3}$ Research on the topic has unearthed positive linear performance effects (e.g. Grant et al. 1988; Vernon 1971) as well as nonlinear patterns in the form of a U (e.g. Capar and Kotabe 2003; Lu and Beamish 2001), an inverted U (e.g. Geringer et al. 1989; Hitt et al. 1997), an S (e.g. Benito-Osorio et al. 2016; Contractor et al. 2003; Riahi-Belkaoui 1998) and, even, an M (e.g. Almodóvar and Rugman 2014).

Some authors have explained these mixed findings based on the different definitions of internationalization used in the literature (e.g. Verbeke and Forootan 2012; Wiersema and Bowen 2011). Constructs such as foreign sales over total sales (FSTS), foreign assets over total assets (FATA), and number of operations do not account perfectly for the degree of dispersion of the multinationals' foreign footprint. As an example, two firms having the same amount of foreign operations could differ in the number and proximity of international markets entered.

To overcome this limitation, several studies have proxied the scope of internationalization either by a country count (e.g. Lu and Beamish 2001; Tallman and Li 1996) or an entropy index that considers both the number of national markets where multinationals operate and how important they are to them (e.g. Hitt et al. 1997). Nonetheless, these variables continue to neglect the inherent characteristics of each of the countries. To account for this fact, one should look at the international dispersion ${ }^{4}$ rather than the degree of internationalization.

For this reason, current research is more concerned with the extent to which multinationals can successfully operate at a global scale. Challenging the existence of a flat world (Friedman, 2005), several studies have found that the LoIF tends to diminish profitability when expanding beyond the home region due to the increased complexity and costs (e.g. Mendoza et al. in press; Oh and Contractor 2014; Rugman and Verbeke 2007). This is particularly salient in the regions often identified in the regionalization literature (e.g. Banalieva et al. 2012; Rugman and Verbeke 2004, 2008; Verbeke et al. 2016), which conform the so-called Triad; namely, European Union (EU), North American Free Trade Agreement (NAFTA), and Asia Pacific.

However, this research stream ignores that there can be varying degrees of intra and interregional heterogeneity (Galán and González-Benito 2006), especially in institutional terms. For instance, although Spain and Germany are both members of the EU, they do not share the same cultural traits (Ronen and Shenkar 2013) or legal system (La Porta et al. 1998). This is an important limitation, as recent works by Banalieva and Robertson (2010), Chao and Kumar (2010), Konara and Shirodkar (2018), Shirodkar and Konara (2017) and $\mathrm{Wu}$ and Salomon (2016) evidence that institutions play a crucial role in the profitability that multinationals ultimately achieve.

\footnotetext{
${ }^{3}$ Please note that in this paragraph we have only featured those works defining performance in terms of profitability. However, additional papers have used either market measures (e.g. Collins 1990; Michel and Shaked 1986) or a combination of both market and accounting measures (e.g. Dittfeld 2017; Lu and Beamish 2004; Thomas and Eden 2004) as their dependent variables of performance.

${ }^{4}$ For the purposes of this study, we follow Asmussen and Goerzen's (2013) definition of dispersion; that is, the extent to which the international operations differ in their proximity to the home base of the focal multinational.
} 
To capture the effect of both geographic and institutional differences on profitability, other researchers such as Miller et al. (2016) have calculated a factor containing Ghemawat's dimensions of cultural, administrative, geographic and economic distance (2001). Although this measure paints a more complete picture of how cross-national differences affect profitability, it does not unpack the nuanced effect of each element of distance. For this reason, and taking the above into account, in the remaining of the paper we set to examine how different facets of the LoF (cultural, regulatory and regional) affect firm profitability as well as the industry characteristics that make firms better able to face the downsides of internationalization.

\section{Hypotheses}

Host country institutions are one of the defining contextual elements of the profitability of multinationals (Peng et al. 2009). Particularly, cross-country institutional differences are one of the reasons behind differentials in performance among multinationals (Bamiatzi et al. 2016; Carney et al. 2019; Makino et al. 2004). Institutions set the rules of the game for firms, defining the type of practices that are accepted and welcomed, both formally and informally (North 1990).

Informal institutions encompass the customs, values and norms that shape human behavior (North, 1991). Culture often serves as a proxy of informal institutions (e.g. Arregle et al. 2016; Estrin et al. 2016; Holmes Jr. et al. 2013). Prior literature has offered a wide range of definitions of the concept of culture, which has evolved over time (Beugelsdijk et al. 2017). In this paper, we conceive culture as a shared set of values and social norms that is transmitted across generations and distinguishes the members of a group from others (Berry and Poortinga 2006; Hofstede and Bond 1988; Ronen and Shenkar 2013). Meanwhile, formal institutions comprise constitutions, laws and property rights (North, 1991). Differences in formal institutions are usually attributed to the legal origin of the countries (La Porta et al. 1998; North 1991). Previous studies have shown that the origin of legal systems impact the regulations governing countries (e.g. Botero et al. 2004; Djankov et al. 2002). Moreover, they affect economic and social outcomes (La Porta et al. 2004).

Entering a new country thus requires multinationals to learn to play by the informal and formal rules of the game; that is, they need to understand the underlying cultural and regulatory principles leading the nation (Globerman and Shapiro 2009; Hitt et al. 2004; Luo and Peng 1999). This means increasing the number of institutional contexts they interact with (Keim and Hillman 2008; Meyer and Tran 2006), which facilitates the emergence of liabilities stemming from the lack of legitimacy in the host country as well as the difficulties in transferring and acquiring firm-specific assets and routines (Gaur and Lu 2007; Kostova 1999; Kostova and Zaheer 1999). In this regard, regional integration offers an opportunity for institutional harmonization that lessens variations across countries (Moschieri et al. 2014), while facilitating economic exchanges and aggregation opportunities within the same region (Ghemawat 2007).

Certainly, a more globally dispersed footprint may bring benefits to multinationals in terms of arbitrage (Ghemawat 2007; Kogut 1985) and learning opportunities (Zhou and Guillén 2015). Nevertheless, the above arguments suggest that entering new institutional contexts also aggravates the LoF (Hymer 1976; Zaheer 1995). As previously mentioned, we operationalize international dispersion by considering the three dimensions of the LoF identified by Asmussen and Goerzen (2013): intercultural, interregulatory, and interregional. ${ }^{5}$ Drawing from the institution-based view (e.g. Peng 2002; Peng et al. 2008; Peng et al. 2009), we expect that, on average, the increased costs of internationalization stemming

\footnotetext{
${ }^{5}$ Compared to Asmussen and Goerzen (2013), we relabel the institutional elements as regulatory to avoid any potential confusions. We do so because the institution-based view considers that both culture and regulations are part of the institutional context of a country (North 1990).
} 
from institutional barriers and cross-country differences will outweigh its benefits since the former are much more certain than the latter. In other words, multinationals will always be required to address institutional differences, but the expected synergies of the international expansion cannot be taken for granted. In this regard, some multinationals may be overconfident in their ability to capture synergies from the increased dispersion of their foreign presence (Picone et al. 2014) or may just follow wrong strategies (Rumelt 2011).

On this basis, we propose that multinationals will be better shielded against the LoF if they operate in industries where: 1) the importance of cultural fit in products is low; 2) firms possess regulatory expertise; and 3) there are limited aggregation opportunities at the regional level. As noted earlier, we argue that infrastructure industries fit this description.

\subsection{Importance of cultural fit}

Even though expanding to diverse locations may widen multinationals' learning opportunities (García-García et al. 2017; Gomez-Mejia and Palich 1997; Morosini et al. 1998), the dominant view in the IB literature is that internationalizing to culturally diverse countries is detrimental to performance due to the increased complexity and costs that it entails (Beugelsdijk et al. 2018). The more dissimilar the cultures where multinationals operate, the harder it is to share common practices (Kostova et al. 2018) and know-how (Madhok 1997) across locations. Moreover, cultural differences complicate gaining social legitimacy in comparison with local incumbents (Zaheer 1995), which makes it harder to convince customers to switch their purchases from them to foreign newcomers. Cultural differences with the end customers are particularly important in industries where firms sell products defined by cultural attributes (Ghemawat 2001) as well as in those where there are close relationships between firms and customers (Javalgi et al. 2014).

The exit of Idilia Foods from the Chinese market provides a good illustration of the difficulties of operating in countries with differing cultural norms and values. ${ }^{6}$ The Spanish food group Nutrexpa (now divided into Adam and Idilia Foods) entered China in 1990 encouraged by the size of the country's potential customer base. They chose to go in the market with Cola-Cao, a cocoa preparation for hot milk that has been one of their star products in the home market for over 70 years. To increase their likelihood of success in China, they adapted and rebranded the product with the phonetically similar name GaoLeGao (meaning "happy, tall, happy"). Despite all the efforts, they faced enormous difficulties in the country, arising from the misfit between their products and the Chinese consumption patterns. By the time they got it right with sweet snacks, the product was so different from the rest of their portfolio that they decided to sell their Chinese venture to the Filipino company Liwayway and exit the market in 2015.

As Joan Cornellà (former General Manager of Cola-Cao Food Tianjin Ltd.) once explained, "the cost of learning has been very high. We have been here for 22 years and nowadays, if we had to change, of course we would change many things because we have already done the learning. When we entered, we did not take into account either the big cultural differences (between China and Spain) or the consumption patterns of Chinese consumers, and nowadays with all these lessons I think we would not need to "waste" so much time studying the market in depth, but we would correct many mistakes that we have made."7

Based on the above arguments, we expect to find a negative linear relationship between intercultural dispersion and profitability; that is, operating across different national cultures results in

${ }^{6}$ Example extracted from: Cola Cao abandona China: Idilia Foods vende su planta de GaoLeGao al filipino Liwayway, La Vanguardia, 17 December 2015.

7 Nutrexpa in China, ICEX, 13 June 2013. Available at https://www.youtube.com/watch?v=IAAv8pcZfvQ. Last accessed 6 September 2019. 
lower profitability when multinationals enter new markets due to the increased costs and complexity. Hence, we propose that:

\section{Hypothesis 1: Intercultural dispersion reduces profitability.}

Ghemawat (2001) suggests that infrastructure firms are not particularly affected by cultural differences due to the nature of their products. They need to be granted a license or contract—or acquire another firm that has them - to operate both at home and abroad (Bonardi 2004; Fernández-Méndez et al. 2015; Henisz 2003); and governments tend to grant contracts and licenses to foreign firms based on project execution skills rather than cultural affinity. Project execution skills involve the ability to plan and execute large-scale projects in a timely fashion by integrating and adapting the technologies and subsystems provided by other firms (Amsden and Hikino 1994). This is particularly vital in developing countries, where governments are concerned with properly filling infrastructure voids to foster economic development (Fernández-Méndez et al. 2015).

The importance of project execution skills instead of cultural fit is highlighted in the international expansion of the Spanish infrastructure company Acciona, which has projects scattered all around the globe. José Valén (Contract Manager and Tender Director at Acciona) knows about the relevance of doing things properly, especially in difficult international markets with significant cultural differences: "We (people in business development) first go into an uncharted territory, very aggressive, very protective. Nobody likes outsiders coming to the market with new ideas. Winning the contract is easy, but then you have to carry out the job. And when you have managed to finish the first contact and you can demonstrate that you can walk the talk and they can see the finished infrastructure on site, that is when we show that we can do it and we can do it well". ${ }^{8}$ Taking all these arguments into account, we suggest that:

\section{Hypothesis 2: The negative linear relationship between intercultural dispersion and profitability is flatter for infrastructure firms.}

\subsection{Degree of regulatory expertise}

Apart from culture, formal institutions also affect the possibilities that multinationals have of succeeding in foreign markets. Different regulations provide arbitrage opportunities that multinationals can exploit to their own benefit (Jackson and Deeg 2008; Konara and Shirodkar 2018; Mallon and Fainshmidt 2017). Furthermore, greater regulatory dispersion sends positive signals to investors, especially when multinationals venture into countries with strong creditor rights (Gande et al. 2009). Yet scholars often find that dealing with distant formal institutions is bound to have a negative impact on profitability (Banalieva and Robertson 2010; Shirodkar and Konara 2017; Wu and Salomon 2016). As regulatory dispersion increases, so do the obstacles in transferring the accumulated knowledge to host countries (Fernández-Méndez et al. 2018; Konara and Shirodkar 2018; Kostova and Roth 2002; Rangan and Sengul 2009). In addition, business practices are usually developed under a specific legal system. Therefore, the effectiveness of these practices can be compromised when firms venture into countries with a different legal system.

Crimidesa, the world's largest sodium sulfate exporter, learned this lesson the hard way. ${ }^{9}$ The Spanish multinational set up a joint venture in the Chinese district of Hongze with some local authorities and a Chinese group to exploit a sodium sulfate deposit and run a factory. After two years and a tenmillion-dollar investment, they discovered that their Chinese partners had never transferred the mining

\footnotetext{
${ }^{8}$ La financiación es el gran reto de las constructoras en el exterior, El Economista, 3 October 2015.

${ }^{9}$ Example extracted from: Aprender a hacer negocios en China, El País, 26 June 2005; and Cuentos y cuentas en China, El País, 22 May 2005.
} 
rights to them. Even though Crimidesa ended up recovering most of their investment, they felt swindled by the Hongze authorities. The issues mainly stemmed from contracts in China not being as binding as in Western economies - something the Spanish multinational was not aware of.

As a result of the differences between regulations, learning pressures are bound to increase, particularly for those multinationals that are not conversant in dealing with governmental actors. Given the difficulties in generating and transferring regulatory knowledge, we submit that:

\section{Hypothesis 3: Interregulatory dispersion reduces profitability.}

Foreign governments often scrutinize infrastructure firms more than those from other industries (Doh et al. 2004; Ramamurti 2003; Sawant 2010). Since governments assign projects through competitive bids, the ability of infrastructure firms to manage different regulatory contexts is paramount to obtain the best possible outcome from negotiations. Losing a bid implies losing a market opportunity, which is likely to impact the firm's profitability negatively. However, winning a bid may not lead automatically to higher returns. If a high number of firms compete for a license or contract, the margins of the winning firm will tend to be lower (Athias and Nuñez 2008; Dyer and Kagel 1996). This will prompt the appearance of the so-called "winner's curse" (Capen et al. 1971); that is, the highest bidder winning the bid at the expense of achieving poor or even negative returns. In addition, winning a bid does not guarantee success in the long run, especially in politically risky countries where the investments can be expropriated (FernándezMéndez et al. 2015; Henisz 2002; Sawant 2010).

Although governmental control may deter the profitability of infrastructure firms by restricting their internationalization choices, it also gives them the expertise to deal with different formal institutions. Multinationals proficient in setting up lobbying campaigns and laying out influence strategies, especially if they have ties to other firms and individuals in the country, will emerge as winners (Henisz 2003). Their continuous interaction with different politicians and regulators will contribute to the development of a dynamic capability to adapt to new institutional environments. The success of the Spanish bus service firm ALSA (Automóviles Luarca, S.A.) in China, where the process of obtaining licenses is far more complex than in other countries, is a good illustration of this capability. ${ }^{10}$

José Cosmen (founder of ALSA) discovered China's need for more developed transportation services during a business trip to the country and decided to invest there in the 1980s. Back then, the Chinese government did not allow foreign firms to operate bus services, so ALSA could only offer taxi transportation services in Shenzen, and through a joint venture with local partners. The firm considered this operation a good opportunity to learn how to do business in China and build strong relationships not only with local partners, but also with governments and regulators. Andrés Cosmen - one of the sons of ALSA's founder and the person responsible for the expansion of the multinational in China-highlights networking with Chinese partners and administrators as one of the reasons why they succeeded in the country (Cosmen 2004). Indeed, when in 1990 the Chinese government gave foreign investors the freedom to operate bus services, ALSA was fully prepared to take the next step. They set up new joint ventures and started offering services that the Chinese population had never seen before, such as regular schedules and modern coaches with comfortable seats. Nowadays, the multinational's expertise in navigating the market has even motivated the creation of an import-export subsidiary whose mission is helping other multinationals operate in China.

The case of ALSA in China shows that infrastructure firms are in a better position to navigate different institutional contexts than their non-infrastructure counterparts thanks to their frequent

${ }^{10}$ Example extracted from Guillén and García-Canal (2010). 
interactions with regulators and government actors in their daily activities. Accordingly, we formulate the following hypothesis:

\section{Hypothesis 4: The negative linear relationship between interregulatory dispersion and profitability is flatter for infrastructure firms.}

\subsection{Regional aggregation opportunities}

Regional integration softens institutional discrepancies between countries (Moschieri et al. 2014). Moreover, countries in regions such as the EU, NAFTA and Asia Pacific are close-by, which reduces the obstacles of geographic distance like travel, transportation, and coordination across time zones (Asmussen and Goerzen 2013). In turn, this facilitates delivering economies of scale by integrating operations at the regional level (Ghemawat 2007).

Firms that have a taste for interregional expansion fail to reap the benefits of a higher institutional uniformity and geographic proximity. This, in turn, supports the negative impact of interregional expansion on firm profitability that researchers have often found in the existing literature (e.g. Almodóvar and Rugman 2014; Oh and Contractor 2014; Oh et al. 2015; Qian et al. 2010; Qian et al. 2013). The plans to move the production activities of Spanish fashion group Mango from Asia back to Europe are a good illustration of the obstacles that some multinationals face due to interregional dispersion. In the words of Daniel López (Vice President of the Spanish group): "Fast fashion is part of the DNA of our company and, to be more receptive in the market, we accepted to move in the near future part of the production from countries like China, Bangladesh and India to closer places such as Spain, Turkey and Italy."11 All in all, given the difficulties that multinationals often face when spreading international operations across regions, we expect that:

\section{Hypothesis 5: Interregional dispersion reduces profitability.}

Infrastructure firms work on a project-by-project basis. This allows host governments to act as deal makers or deal breakers in their investments (Ramamurti 2003), shaping the market opportunities that they can pursue. For this reason, infrastructure firms often favor multidomestic strategies, negotiating entry and setting up operations in each country separately (Bonardi 2004). This one-country-at-a-time approach ultimately entails that infrastructure firms cannot easily split their value chain across locations (Bonardi 2004; Guillén and García-Canal, 2010). Consequently, they cannot fully benefit from the economies of scale of their foreign operations, which is one of the main advantages highlighted in prior studies examining the relationship between internationalization and performance (Abdi and Aulakh 2018). Moreover, each operation normally requires a larger deployment of resources as the firm has to build it up from scratch.

Nonetheless, the lack of opportunities for integration of their activities at a regional level that we have previously described can also prove a favor in disguise. Despite restricting opportunities to take advantage of cost efficiencies, we expect that building the whole operation from scratch in each host country eases the coordination of foreign ventures due to the absence of links between countries that trigger the downsides of geographic distance. That is why the managers of these firms do not feel uncomfortable at all displaying multidomestic strategies. As the former CEO of Telefónica once said, "in this company we always say that we are not a multinational firm, but rather a multidomestic company, and

${ }^{11}$ Lopez (Mango): “Aumenteremo il reshoring in Spagna e Italia”, Pambianco News, 23 March 2017. 
the message conveyed to each executive is precisely this one: we are a company deeply rooted in each of the countries in which we operate." 12 As such, we suggest that:

\section{Hypothesis 6: The negative linear relationship between interregional dispersion and profitability}

is flatter for infrastructure firms.

\section{Methods}

\subsection{Sample}

Our sample comprises all non-financial Spanish firms listed in the Madrid Stock Exchange in $1990(n=103)$ over a 22-year span $(1986-2007) .{ }^{13}$ We chose neither the research setting nor the timeframe arbitrarily. Spain offers a unique scenario to study the outcomes of international dispersion from an institutional perspective. Using this country to perform the analyses addresses concerns about varying degrees of intra and interregional institutional heterogeneity. For instance, as we mentioned before, Spain and Germany are both members of the EU. However, they do not share the same cultural traits (Ronen and Shenkar 2013) or legal system (La Porta et al. 1998). In addition, the Spanish context allows us to present a more complete picture of the consequences of international dispersion on profitability than alternative research settings given that Spanish outward FDI experienced a significant growth only after the country's entrance in the European Economic Community (the current European Union) in 1986. We established 2007 as the final year of our timeframe to counter any potential biases in the findings resulting from the 2008 global financial crisis.

To conduct our analyses, we retrieved the data on Spanish FDI operations from the Systematic Database on International Operations of Spanish Companies, developed under the sponsorship of the Spanish Institute for Foreign Trade, ICEX (see Guillén and García-Canal 2007). We also consulted other sources of information to build additional variables (e.g. COMPUSTAT, DATASTREAM, Thomson Reuters SDC Platinum, the Spanish Securities Market Commission online reports, news databases, and the websites of the firms included in our sample).

\subsection{Analytical Approach}

In this paper, we focus on analyzing the effect of international dispersion on profitability and the extent to which cross-industry differences moderate this relationship. Because geographic diversification strategies are bounded to be affected by self-selection (e.g. Dastidar 2009), we accounted for this issue by implementing Heckman's two-step estimation method (1979) using STATA 14. In the first step, we estimated a robust panel-data probit to predict if firm $i$ was already internationalized in year $t{ }^{14}$ We then calculated the inverse Mills ratio, which we introduced as a control variable for self-selection in the second stage (robust random-effects regressions).

This second stage only comprises observations from firms operating abroad and, specifically, for the years when they are internationalized. For this reason, whereas the first stage includes 1,179 firm-year observations and 103 firms, the second one consists of 689 firm-year observations and 62 firms. We describe in more detail the measures that we use in our analysis in the following subsections. We lagged one period all independent and control variables to account for potential reverse causality issues and to better capture the effect of international dispersion on profitability (Wan and Hoskisson 2003).

\footnotetext{
${ }^{12}$ César Alierta, CEO of Telefónica, Diario 155, 26 June 2001, p. 21.

13 At this point, we shall note that our panel-data sample is not balanced. Some of the companies included in our study got delisted or merged during the period of analysis. In addition, there are some non-systematic missing observations.

${ }^{14}$ A previous version of this first stage appears on García-García et al. (2017).
} 


\subsection{First-stage variables: the internationalization decision}

The dependent variable in the first stage aims to capture whether a firm $i$ had any FDI stock within a certain year $t$. We proxy it with a dummy that takes the value of one if the firm had invested abroad from 1986 to the end of year $t$, and zero otherwise. Following Dastidar (2009), we regressed our dependent variable on the lagged values of firm and industry characteristics. We also introduced a year control to account for the specific year of the observation.

At firm level, we include the following variables: ${ }^{15}$ size (total sales); proprietary technology (number of patents accrued by the firm since the year of its establishment); leverage (long-term debt to total assets); liquidity (cash and cash equivalents to total liabilities); operating margin (EBIT/Sales); mergers (accumulated number of mergers the firm had gone through since its founding); ${ }^{16}$ firm age (number of years since inception); family ownership (percentage of stock held by the founder and/or their family); percentage of stock owned by the firm's Board; percentage of stock owned by the Spanish government; and a dummy denoting whether the CEO was also the Chairman of the board of directors of the firm.

At the industry level we include the firm's global mimetic behavior, defined as the percentage of firms that are geographically diversified within an industry in a certain year. Furthermore, we use a dummy variable taking the value of one if the firm operates in infrastructure industries, and zero otherwise. ${ }^{17}$ As previously mentioned, we follow Fernández-Méndez et al. (2015) and consider to be infrastructure firms those operating in electricity, water, oil, gas, transportation, telecommunications, and construction. This categorization is also consistent with the bulk of research analyzing infrastructure firms (Guthrie 2006; Kirkpatrick et al. 2006; Parker 2003; Ramamurti and Doh 2004; Sawant 2010). It should be noted that construction firms are featured in this category because most of their activities revolve around the development and operation of large state-funded infrastructure projects (Fernández-Méndez et al. 2015; Grimsey and Lewis 2007: 2). We classified the remaining industries as non-infrastructure —other soft services $;{ }^{18}$ other hard services; ${ }^{19}$ food and drink; iron and steel; machinery and equipment; building materials; chemical products and medical equipment; and stationery and office supplies. We also include dummies to account for the focal firm's primary industry of operation.

\subsection{Second stage: international dispersion and profitability}

In the second stage we use profitability as our dependent variable. We define profitability as the firm's return on assets (ROA). This measure is the most commonly used in studies analyzing the performance outcomes of internationalization (e.g. Abdi and Aulakh 2018; Lu and Beamish 2001; Miller et al. 2016; Ruigrok et al. 2007). To smooth out yearly fluctuations, we calculated a three-year moving

15 We retrieved the financial data from COMPUSTAT, DATASTREAM, the Spanish Securities Market Commission, and the firms' websites. We gathered the data on proprietary technology from ESPACENET. This platform is available online at https://worldwide.espacenet.com/ (Last accessed 6 September 2019). We extracted the data to build the ownership and management variables from press releases, directories (DICODI, DUNS, The Maxwell Espinosa Shareholders Directory), and the works of Vergés (1999, 2010).

${ }^{16}$ This variable only includes domestic mergers with other companies from our sample. We ran a robustness test by excluding the firms involved in mergers from our regressions. The pattern of results remained unchanged. We do not report the findings due to space restrictions. However, they are available upon request.

${ }^{17}$ We exclude firms operating in banking and financial services from our analyses because they normally have specific accounting standard (Lemmon and Lins 2003).

${ }^{18}$ We define soft services as those that require simultaneous production and consumption. Consequently, the firm and the customer base must be co-located (Guillén and García-Canal 2010).

${ }^{19}$ Hard services are those in which production and consumption can be separated. Therefore, they can be exported at arm's length (Erramili 1990). 
average of ROA at time $\mathrm{t}-1, \mathrm{t}$, and $\mathrm{t}+1$, as previously done by authors such as Chang and Rhee (2011) and García-García et al. (2017).

Our key explanatory variable is international dispersion. We followed Asmussen and Goerzen (2013) to operationalize this variable, thus considering intercultural, interregulatory, and interregional dispersion. We chose clusters over continuous distance measures because Asmussen and Goerzen (2013) and Gupta et al. (2002) contend that country clusters offer a good summary of interinstitutional and interregional similarities and differences.

We measure intercultural dispersion as the number of different cultural blocs where multinationals operate. We specify said cultural blocs based on the classification developed by Ronen and Shenkar (2013). Specifically, we used the 11 global clusters that these authors found in their study; namely, Arab, Near East, Latin America, East Europe, Latin Europe, Nordic, Germanic, African, Anglo, Confucian, and Far East. We exclude from the definition of the variable Spain's home cultural bloc; namely, Latin Europe.

We calculate interregulatory dispersion as the number of different regulatory blocs where multinationals operate. We relied on the classification of legal systems by La Porta et al. (1998) to delineate them. According to their work, we created six categories: British common-law, French civil-law, German civil-law, Scandinavian civil-law; socialist, and mixed legal system. Mirroring our definition of intercultural dispersion, we do not account for Spain's home regulatory bloc; namely, French civil-law. We focus on legal systems because former studies have found that countries with the same legal origin possess similar regulations (Botero et al. 2004; Fernández-Méndez et al. 2015).

Regarding interregional dispersion, we define it as the number of different regional clusters where multinationals operate outside of Spain's home region. According to the Triad region classification used in previous studies (e.g. Oh and Contractor 2014; Rugman and Verbeke 2004; Verbeke et al. 2016), we consider Spain's home region to be the EU. Specifically, we consider that Spain's core region is the EU15. To account for all the destinations of the Spanish FDI, we added a category named "Other" to the two remaining blocs of the Triad (i.e. NAFTA and Asia Pacific).

Our moderating variable is the same dummy that we used in the first stage, which takes the value of one if the firm operates in infrastructure industries, and zero otherwise. Table 1 summarizes the levels of international presence and dispersion displayed by the multinationals in our sample according to the industry where they operate. The table contains information about the number of firm-year observations belonging to domestic and multinational firms. It also presents the mean and standard deviations of the multinationals' international intensity (number of foreign operations carried out), international scope (number of countries entered) and each of the three dimensions of international dispersion for each industry, the infrastructure and non-infrastructure subsamples, and the overall sample. We can observe that infrastructure firms tend to favor expanding beyond domestic borders, undertaking more foreign investments and venturing into more countries. Furthermore, their international footprint is more dispersed across cultural, regulatory and regional clusters than that of their non-infrastructure counterparts. Particularly, construction multinationals seem to have a taste for dissimilar countries. At the other extreme, multinationals operating within the categories of "Other soft services" and "Stationery and office supplies" display some of the lowest levels of international dispersion in the sample.

Please insert Table 1 about here 
To rule out alternative explanations, we added some firm-level variables included in the first stage as controls in our second-stage regressions: size; proprietary technology; leverage; liquidity; operating margin; family, Board and state ownership; CEO duality; and firm age. Since prior works have found a close link between international experience and profitability (Goerzen and Beamish 2005), we also added the number of years that a firm had been operating abroad. Additionally, we introduced a variable to control for the entry modes used by firms when expanding abroad and defined it as the percentage of wholly-owned subsidiaries. Furthermore, we entered the inverse Mills ratio as a control for self-selection. Finally, we included year and industry dummies as controls in all our models.

Table 2 exhibits the correlations and descriptive statistics of the main variables included in this second stage. As can be extracted from this table, there are no high correlations Therefore, multicollinearity does not seem to be an issue. Our Variance Inflation Factors (VIFs) analysis further supports that there is no significant multicollinearity as all the mean VIF values of the regressions are well below the recommended cutoff value of 10 proposed by Kutner et al. (2004: 409).

Please insert Table 2 about here

\section{Results}

Table 3 shows the robust panel-data probit of the internationalization decision. Because this stage is only instrumental in our core analysis, for the sake of brevity we only report the estimates. Nonetheless, it shall be noted that the Infrastructure industries variable is not significant, meaning that belonging to these industries does not make firms more prone to internationalization.

Please insert Table 3 about here

Table 4 reports the estimates from the second-stage robust random-effects regressions using three separate models that differ in the dimension of international dispersion included as independent variable: intercultural dispersion (Model I), interregulatory dispersion (Model II), and interregional dispersion (Model III). Instead of entering these three variables in a sole model, we used three separate ones to prevent any biases from the high pairwise correlations between the three dimensions of international dispersion.

Please insert Table 4 about here

Consistent with Hypothesis 1, the more cultural clusters that a multinational enters, the lower its profitability $(\beta=-0.773, p=0.029)$. This relationship is flatter for infrastructure multinationals $(\beta=0.729$, $\mathrm{p}=0.029$ ), in line with Hypothesis 2 . We also find support for Hypotheses 3 and 4 in that there is a LoF when operating across different regulations $(\beta=-1.499, \mathrm{p}=0.023)$ that infrastructure multinationals are more capable of managing $(\beta=1.483, p=0.027)$. Similarly, the negative and significant coefficient of interregional dispersion $(\beta=-1.154, \mathrm{p}=0.051)$ offers support for the LoIF discussed in Hypothesis 5 . Once again, infrastructure multinationals seem to be better equipped to handle an increased interregional presence $(\beta=1.589, \mathrm{p}=0.004)$, as we argue in Hypothesis 6 .

Figures 1 to 3 illustrate the moderating effects included in our regressions. Figure 1 shows that increasing the number of cultural clusters where multinationals operate leads to the emergence of an intercultural LoF, being this liability less acute for infrastructure multinationals. The same applies to the 
negative relationships between interregulatory dispersion and profitability depicted in Figure 2 . The positive effect displayed for infrastructure multinationals in the different interactions is even more pronounced in Figure 3, which presents the effect of interregional dispersion on profitability. In it we can see that the negative relationship between interregional dispersion and profitability observed for noninfrastructure firms turns into a positive one for infrastructure firms.

Please insert Figures 1 to 3 about here

To conclude this section, it would be interesting to review the significance of our control variables. Our estimates indicate that the operating margin has a consistent positive effect on profitability. By contrast, proprietary technology seems to have a negative impact on the returns achieved by the firms. Finally, our inverse Mills ratio is negative and significant across all models, thus emphasizing the need to control for self-selection in the study.

\section{Robustness tests and additional analyses}

The findings presented in this study are robust to the redefinition of both the dependent and independent variables. Although we only report some of these estimates due to space restrictions, all of them are available from the authors upon request. First, we performed a robustness test by using $\mathrm{ROA}_{t}$ (ROA in the current year) instead of $\mathrm{ROA}_{\mathrm{t}-1, \mathrm{t}, \mathrm{t}+1}$ (three-year moving average of ROA) as our dependent variable in the second stage. Our estimates remained unchanged.

Second, we reran our second-stage analysis applying Ghemawat's CAGE framework (2001). To do so, we built a comprehensive independent variable encompassing cultural, administrative, geographic, and economic distances. Building on Campbell et al. (2012) and García-García et al. (2017), we used principal common factor analysis with varimax rotation to create a single measure of the weighted standard deviations of distance between Spain and their host country base. We defined geographic distance as the pairwise distance between the capitals of the countries (in kilometers). We specified the remaining distance dimensions using data extracted from the cross-national distance database developed by Berry et al. (2010). ${ }^{20}$ The single factor had an eigenvalue of 2.64 and accounted for $66.0 \%$ of the overall variance. Our original results held.

Please insert Table 5 about here

Third, we tested whether our findings were robust to the inclusion of the three dimensions of international dispersion (cultural, regulatory and regional) in the same model. Due to the high correlation between these dimensions, we once again conducted principal common factor analysis with varimax rotation to create a measure of overall international dispersion. The single factor had an eigenvalue of 2.40 and accounted for $80.2 \%$ of the overall variance. The inclusion of the new international dispersion variable did not affect our results.

Please insert Table 6 about here

20 This database is available at the Penn Lauder CIBER webpage. 
Fourth, one could argue that there may be different levels of dispersion across dimensions. In an additional robustness test, we created a measure containing the number of dimensions where the firm is more dispersed than the average of the sample. To build the variable, we first calculated the average intercultural, interregulatory, and interregional dispersions of the observations in our sample. For each international dispersion dimension, we then created a dummy variable taking the value of one if the firmyear observation was above the average, and zero otherwise. Finally, we added the firm-year observations of the three dummy variables, which returned an index ranging from 0 to 3. Once again, entering this variable did not alter our findings.

Please insert Table 7 about here

Fifth, our results were also robust to modifications in the definition of interregional dispersion. Since the EU welcomed new members during the period of our study, we ran a robustness check accounting for the 2004 and 2007 EU enlargements. Furthermore, we refined the category "Other" that we had previously created to acknowledge those destinations outside the Triad by grouping the countries in the next categories: Africa, America (excluding NAFTA), Europe (excluding EU-15), and Asia (excluding Asia Pacific). Because interregional dispersion places a strong emphasis on coordination, we performed an additional test by specifying this variable as the percentage of the firm's country portfolio outside of its home region (the higher the number of countries outside the home region, the harder it may be to coordinate operations). In all cases our results held.

Finally, to account for a wider range of intangible assets, we changed our proprietary technology measure to a lagged Tobin's q-calculated following Chung and Pruitt's (1994) formula. Former studies have considered this ratio as an appropriate proxy of the value of the intangible assets of the firm (e.g. Berry 2006; Dowell et al. 2000; García-Canal and Guillén 2008; Villalonga 2004) as well as its future investment opportunities (e.g. Carow et al. 2004). Our findings were not altered.

\section{Discussion and Conclusions}

This paper adds to the debate on the limits of successful international expansion by examining the relationship between international dispersion and profitability. Traditionally under-researched, several authors have called for more contributions on this topic (e.g. Aguilera et al. 2015; Avloniti and Filippaios 2018; Bae and Salomon 2010; Contractor 2007; Fortwengel 2017), especially taking into account that it is unrealistic to assume that it will impact all firms and/or industries equally (Zhou and Guillén 2016). Our main contribution is to show the existence of cross-industry differences in the relationship between international dispersion and profitability, being firms in infrastructure industries less affected by the LoF than the remaining ones.

We operationalized international dispersion by considering the three dimensions identified by Asmussen and Goerzen (2013): intercultural, interregulatory, and interregional. Drawing from the institution-based view (e.g. Peng 2002; Peng et al. 2008; Peng et al. 2009), we suggest that, on average, the downsides of operating across different institutional contexts outweigh the benefits of international dispersion, thereby lowering profitability. Based on our theoretical framework, we would also expect infrastructure multinationals to be better equipped to face the LoF because they operate in industries where: 1) the importance of cultural fit in products is low; 2) firms possess regulatory expertise; and 3) there are limited aggregation opportunities at the regional level.

Our results support the decline in profitability as multinationals increase the intercultural, interregulatory and interregional dispersion of their internationalization. However, our most important 
result relates to the fact that infrastructure industries are less affected by any of the three LoF dimensions considered than the rest. Indeed, our core estimates show that infrastructure multinationals even profit from venturing outside the boundaries of their home region, thus challenging the existence of a LoIF in these industries. This finding is in line with those obtained from our additional analyses using CAGE and above-average international dispersion as our independent variables. In both cases infrastructure multinationals seem to gain from spreading their international presence. Taking these results as a whole, one could even say that instead of suffering from the LoF, infrastructure multinationals may benefit from what Mallon and Fainshmidt (2017) call an asset of foreignness. As we have previously mentioned, the difficulties in coordinating international operations across countries lead infrastructure multinationals to adopt multidomestic strategies. Paradoxically, this grants them more freedom to pursue profitable investment opportunities wherever they are, allowing them to benefit from international dispersion more than their non-infrastructure counterparts.

It could be argued that our results are somewhat biased by the home region in our sample (the EU15), since the most profitable opportunities for the expansion of infrastructure firms are in the developing world; that is, outside the EU-15 (especially in Latin America, in the case of Spanish multinationals). To rule out this alternative explanation, we created two variables to rerun our regressions; namely, percentage of developing countries and percentage of developed countries outside the EU-15. ${ }^{21}$ Our results confirm that increases in international dispersion both in developing countries and developed countries outside the EU-15 raise the profitability of infrastructure industries. Hence, the degree of development of the host countries of destination does not seem to be a factor affecting our results. We do not report these results due to space restrictions. Nonetheless, they are available from the authors upon request.

Overall, our findings highlight the importance of putting the relationship between internationalization and profitability into context, which has been urged by Dittfeld (2017), Kim et al. (2015) and Liou and Rao-Nicholson (2019), among others. In this regard, our paper focuses on industrylevel contingencies. However, we believe that our framework could be extended to the firm level by analyzing the firm attributes that reduce the LoF. For instance, the findings of Oh and Contractor (2014) suggest that product diversification mitigates the performance downturns that multinationals experience when expanding to foreign regions. More recently, Ral-Trebacz et al. (2018) have shown that marketingrelated FSAs can reduce the value erosion associated to interregional expansion. Our framework may help to integrate these results and develop new hypotheses at the firm level. The fact that previous research has found, on average, a negative relationship between international dispersion and profitability does not preclude that some firms may actually maintain or even increase their profitability levels when expanding abroad. For this reason, the factors identified in this study to counter the erosion of firm profitability in the international expansion (i.e. low importance of cultural fit in products; high regulatory expertise; and restricted opportunities for regional-level aggregation) can be useful for establishing criteria to guide the decisions of firms about whether to expand abroad or not.

Apart from the academic contributions, our study also carries important managerial and policy implications. Our findings offer a performance-based explanation to why some firms avoid pursuing a global reach, as previously found by Fisch and Oesterle (2003), Osegowitsch and Sammartino (2008), and Rugman (2003), among others. Expanding to a wide variety of international settings offsets a series of

${ }^{21}$ We followed the UNCTAD and IMF classifications to categorize countries according to their degree of development. In the Developed category, we only included those countries considered as developed by both organizations. All other countries fell in the Developing category. It shall be acknowledged that all developing countries are located outside of the EU-15 boundaries. 
costs that are hardly ever outweighed by the benefits of the foreign expansion and some multinationals are already realizing this. As a consequence, they have entered into "the prudent age of the multinational", in which companies are more cautious about the scope of their international investments. ${ }^{22}$ This will pose additional challenges for governments and policymakers to ensure that their countries are attractive destinations of foreign investments, especially at a time in which institutional complexity seems to be rising rather than declining because of events like Brexit or the threats of US pulling out of NAFTA.

Despite the contributions and implications of our study, it also presents limitations. The first of these relates to the use of a single country setting to carry out our analyses. Although adopting a multicountry setting could have reinforced the external validity of our results, focusing on Spanish firms has the benefit of eliminating home-country variation as a confounding factor (Darandeli and Hill 2016). Besides, the bulk of Spanish foreign investments took place within the timeframe of the study, thus removing left-censoring issues. The second limitation emerges from data restrictions. A lack of access to primary data restricted the empirical operationalization of some of our arguments, such as those related to the pursuit of arbitrage opportunities. We were also unable to gather comprehensive data on the divestments of the multinationals in the host countries. Data restrictions also prevented us from studying the impact of within-country institutional differences and resources and capabilities on the profitability of international strategies.

These limitations open interesting avenues for future research. For instance, scholars could further examine the link between arbitrage and international dispersion, and how it affects performance. They could also build on studies that examine within-country institutional variations (e.g. Kaasa et al. 2014; Taras et al. 2016) to address how they influence the profitability of multinationals. It would also be interesting to know more about entry modes and the role they play in alleviating or amplifying the LoF and its effect on performance. Additionally, new studies could extend the literature on resources and capabilities to the analysis of the relationship between international dispersion and performance since their value depends on the institutional environment of the country (Brouthers et al. 2008). Furthermore, future research could investigate the value of institutional capabilities. Although the whole set of factors that make firms from infrastructure industries less affected by institutional dispersion cannot be fully replicated by firms from other industries, the development of institutional capabilities may be. Recent research by Cuervo-Cazurra et al. (2018) confirms that Latin American firms from a myriad of industries can perform better outside of their home region thanks to the uncertainty management capability developed by being exposed to political risk in their home country. All in all, we expect that our study contributes to additional research that refines our knowledge on the outcomes of internationalization.

\section{References}

Abdi, M., \& Aulakh, P. S. (2018). Internationalization and performance: Degree, duration, and scale of operations. Journal of International Business Studies, 49(7), 832-857.

Aguilera, R. V., Flores, R., \& Kim, J. U. (2015). Re-examining regional borders and the multinational enterprise. Multinational Business Review, 23(4), 374-394.

Allen, L., \& Pantzalis, C. (1996). Valuation of the operating flexibility of multinational corporations. Journal of International Business Studies, 27(4), 633-653.

Almodóvar, P., \& Rugman, A. M. (2014). The M curve and the performance of Spanish international new ventures. British Journal of Management, 25(S1), S6-S23.

${ }^{22}$ The Economist discusses this new attitude of multinationals in the article The retreat of the global company, published on 28 January 2017. 
Amsden, A. H., \& Hikino, T. (1994). Project execution capability, organizational know-how and conglomerate corporate growth in late industrialization. Industrial and Corporate Change, 3(1), 111-147.

Arregle, J. L., Miller, T. L., Hitt, M. A., \& Beamish, P. W. (2016). How does regional institutional complexity affect MNE internationalization? Journal of International Business Studies, 47(6), 697-722.

Asmussen, C. G., \& Goerzen, A. (2013). Unpacking Dimensions of Foreignness: Firm-Specific Capabilities and International Dispersion in Regional, Cultural, and Institutional Space. Global Strategy Journal, 3(2), 127-149.

Athias, L., \& Nuñez, A. (2008). Winner's curse in toll road concessions. Economics Letters, 101(3), 172174.

Avloniti, A., \& Filippaios, F. (2018). Evaluating the effects of cultural and psychic distance on multinational corporate performance: a meta-analysis. Global Business and Economics Review, 20(1), 54-87.

Bae, J.-H., \& Salomon, R. (2010). Institutional distance in international business research. In T. Devinney, T. Pedersen, \& T. Laszlo (Eds.), Advances in International Management, Volume 23, The Past, Present and Future of International Business and Management (pp. 327-349). Bingley: Emerald Group Publishing.

Bamiatzi, V., Bozos, K., Cavusgil, S. T., \& Hult, G. T. M. (2016). Revisiting the firm, industry, and country effects on profitability under recessionary and expansion periods: A multilevel analysis. Strategic Management Journal, 37(7), 1448-1471.

Banalieva, E. R., \& Robertson, C. J. (2010). Performance, diversity, and multiplicity of foreign crosslisting portfolios. International Business Review, 19(6), 531-547.

Banalieva, E. R., Santoro, M. D., \& Jiang, J. R. (2012). Home region focus and technical efficiency of multinational enterprise. Management International Review, 52(4), 493-518.

Bausch, A., \& Krist, M. (2007). The effect of context-related moderators on the internationalizationperformance relationship: Evidence from meta-analysis. Management International Review, 47(3), 319-347.

Benito, G. R. G. (2015). Why and how motives (still) matter. Multinational Business Review, 23(1), 1524.

Benito-Osorio, D., Colino, A., Guerras-Martín, L. Á., \& Zúñiga-Vicente, J. Á. (2016). The international diversification-performance link in Spain: Does firm size really matter? International Business Review, 25(2), 548-558.

Berry, H. (2006). Shareholder valuation of foreign investment and expansion. Strategic Management Journal, 27(12), 1123-1140.

Berry, H., Guillén, M. F., \& Zhou, N. (2010). An institutional approach to cross-national distance. Journal of International Business Studies, 41(9), 1460-1480.

Berry, J. W., \& Poortinga, Y. H. (2006). Cross-cultural theory and methodology. In J. Georgas, J. W. Berry, F. V. d. Vijver, C. Kagitcibasi, \& Y. H. Pootinga (Eds.), Families across cultures. Cambridge: Cambridge University Press. 
Beugelsdijk, S., Kostova, T., \& Roth, K. (2017). An overview of Hofstede-inspired country-level culture research in international business since 2006. Journal of International Business Studies, 48(1), 3047.

Beugelsdijk, S., Kostova, T., Kunst, V. E., Spadafora, E., \& van Essen, M. (2018). Cultural distance and firm internationalization: A meta-analytical review and theoretical implications. Journal of Management, 44(1), 89-130.

Bonardi, J. P. (2004). Global and political strategies in deregulated industries: The asymmetric behaviors of former monopolies. Strategic Management Journal, 25(2), 101-120.

Botero, J. C., Djankov, S., La Porta, R., Lopez-de-Silanes, F., \& Shleifer, A. (2004). The regulation of labor. The Quarterly Journal of Economics, 119(4), 1339-1382.

Brouthers, K. D., Brouthers, L. E., \& Werner, S. (2008). Resource-based advantages in an international context. Journal of Management, 34(2), 189-217.

Buckley, P. J., \& Casson, M. (1976). The future of the multinational enterprise. Macmillan, London.

Campbell, J. T., Eden, L., \& Miller, S. R. (2012). Multinationals and corporate social responsibility in host countries: Does distance matter? Journal of International Business Studies, 43(1), 84-106.

Capar, N., \& Kotabe, M. (2003). The relationship between international diversification and performance in service firms. Journal of International Business Studies, 34(4), 345-355.

Capen, E. C., Clapp, R. V., \& Campbell, W. M. (1971). Competitive bidding in high-risk situations. Journal of Petroleum Technology, 23(6), 641-653.

Carney, M., Estrin, S., Liang, Z., \& Shapiro, D. (2019). National institutional systems, foreign ownership and firm performance: The case of understudied countries. Journal of World Business, 54(4), 244257.

Carow, K., Heron, R., \& Saxton, T. (2004). Do early birds get the returns? An empirical investigation of early-mover advantages in acquisitions. Strategic Management Journal, 25(6), 563-585.

Caves, R. E. (1971). International corporations: The industrial economics of foreign investment. Economica, 38(149), 1-27.

Chang, S. J., \& Rhee, J. H. (2011). Rapid FDI expansion and firm performance. Journal of International Business Studies, 42(8), 979-994.

Chao, M. C. H., \& Kumar, V. (2010). The impact of institutional distance on the international diversityperformance relationship. Journal of World Business, 45(1), 93-103.

Chung, K. H., \& Pruitt, S. W. (1994). A simple approximation of Tobin's q. Financial Management, 23(3), 70-74.

Collins, J. M. (1990). A market performance comparison of US firms active in domestic, developed and developing countries. Journal of International Business Studies, 21(2), 271-287.

Contractor, F. J. (2007). The evolutionary or multi-stage theory of internationalization and its relationship to the regionalization of firms. In A. M. Rugman (Ed.), Regional aspects of multinationality and performance (pp. 11-29). Oxford: Elsevier.

Contractor, F. J., Kundu, S. K., \& Hsu, C. C. (2003). A three-stage theory of international expansion: The link between multinationality and performance in the service sector. Journal of International Business Studies, 34(1), 5-18. 
Cosmen, A. (2004). Los sistemas de gestión de las empresas de transporte en China. Economía Exterior, 30: 85-92.

Cuervo-Cazurra, A., Ciravegna, L., Melgarejo, M., \& Lopez, L. (2018). Home country uncertainty and the internationalization-performance relationship: Building an uncertainty management capability. Journal of World Business, 53(2), 209-221.

Cuervo-Cazurra, A., Maloney, M. M., \& Manrakhan, S. (2007). Causes of the difficulties in internationalization. Journal of International Business Studies, 38(5), 709-725.

Cuervo-Cazurra, A., Narula, R., \& Un, C. A. (2015). Internationalization motives: Sell more, buy better, upgrade and escape. Multinational Business Review, 23(1), 25-35.

Darendeli, I. S., \& Hill, T. L. (2016). Uncovering the complex relationships between political risk and MNE firm legitimacy: Insights from Libya. Journal of International Business Studies, 47(1), 6892.

Dastidar, P. (2009). International corporate diversification and performance: Does firm self-selection matter? Journal of International Business Studies, 40(1), 71-85.

Dittfeld, M. (2017). Multinationality and performance: a context-specific analysis for German firms. Management International Review, 57(1), 1-35.

Djankov, S., La Porta, R., Lopez-de-Silanes, F., \& Shleifer, A. (2002). The regulation of entry. The Quarterly Journal of Economics, 117(1), 1-37.

Doh, J. P., Teegen, H., \& Mudambi, R. (2004). Balancing private and state ownership in emerging markets' telecommunications infrastructure: country, industry, and firm influences. Journal of International Business Studies, 35(3), 233-250.

Dowell, G., Hart, S., \& Yeung, B. (2000). Do corporate global environmental standards create or destroy market value? Management Science, 46(8), 1059-1074.

Dunning, J. H., Fujita, M., \& Yakova, N. (2007). Some macro-data on the regionalisation/globalisation debate: a comment on the Rugman/Verbeke analysis. Journal of International Business Studies, 38(1), 177-199.

Dyer, D., \& Kagel, J. H. (1996). Bidding in common value auctions: How the commercial construction industry corrects for the winner's curse. Management Science, 42(10), 1463-1475.

Eden, L., \& Miller, S. R. (2001). Opening the black box: multinationals and the cost of doing business abroad. Academy of Management Proceedings, C1-C6.

Eden, L., \& Miller, S. R. (2004). Distance matters: Liability of foreignness, institutional distance and ownership strategy. In M. A. Hitt \& J. L. C. Cheng (Eds.), Advances in International Management, Volume 16, Theories of the Multinational Enterprise: Diversity, Complexity and Relevance (pp. 187-221). Bingley: Emerald Group Publishing.

Erramili, M. (1990). Entry mode choice in service industries. International Marketing Review, 7(5), 5062.

Estrin, S., Meyer, K. E., Nielsen, B. B., \& Nielsen, S. (2016). Home country institutions and the internationalization of state owned enterprises: A cross-country analysis. Journal of World Business, 51(2), 294-307. 
Fernández-Méndez, L., García-Canal, E., \& Guillén, M. F. (2015). Legal family and infrastructure voids as drivers of regulated physical infrastructure firms' exposure to governmental discretion. Journal of International Management, 21(2), 135-149.

Fernández-Méndez, L., García-Canal, E., \& Guillén, M. F. (2018). Domestic political connections and international expansion: It's not only 'who you know' that matters. Journal of World Business, 53(2), 695-711.

Fisch, J. H., \& Oesterle, M. J. (2003). Exploring the globalization of German MNCs with the complex spread and diversity measure. Schmalenbach Business Review, 55(1), 2-21.

Flores, R., Aguilera, R. V., Mahdian, A., \& Vaaler, P. M. (2013). How well do supranational regional grouping schemes fit international business research models? Journal of International Business Studies, 44(5), 451-474.

Fortwengel, J. (2017). Understanding when MNCs can overcome institutional distance: A research agenda. Management International Review, 57(6), 793-814.

Friedman, T. (2005). The world is flat: A brief history of the twenty-first century. New York: Farrar, Straus \& Giroux.

Galán, J. I., \& González-Benito, J. (2006). Distinctive determinant factors of Spanish foreign direct investment in Latin America. Journal of World Business, 41(2), 171-189.

Gande, A., Schenzler, C., \& Senbet, L. W. (2009). Valuation effects of global diversification. Journal of International Business Studies, 40(9), 1515-1532.

García-Canal, E., \& Guillén, M. F. (2008). Risk and the strategy of foreign location choice in regulated industries. Strategic Management Journal, 29(10), 1097-1115.

García-García, R., García-Canal, E., \& Guillén, M. F. (2017). Rapid internationalization and long-term performance: The knowledge link. Journal of World Business, 52(1), 97-110.

Gaur, A. S., \& Lu, J. W. (2007). Ownership strategies and survival of foreign subsidiaries: Impacts of institutional distance and experience. Journal of Management, 33(1), 84-110.

Geringer, J. M., Beamish, P. W., \& DaCosta, R. C. (1989). Diversification strategy and internationalization: Implications for MNE performance. Strategic Management Journal, 10(2), 109-119.

Ghemawat, P. (2001). Distance still matters. Harvard Business Review, 79(8), 137-147.

Ghemawat, P. (2003). Semiglobalization and international business strategy. Journal of International Business Studies, 34(2), 138-152.

Ghemawat, P. (2005). Regional strategies for global leadership. Harvard Business Review, 83(12), 98108.

Ghemawat, P. (2007). Why the world isn't flat. Foreign Policy, 159, 54-60.

Glaum, M., \& Oesterle, M.-J. (2007). 40 years of research on internationalization and firm performance: More questions than answers? Management International Review, 47(3), 307-317.

Globerman, S., \& Shapiro, D. (2009). Economic and strategic considerations surrounding Chinese FDI in the United States. Asia Pacific Journal of Management, 26(1), 163-183.

Goerzen, A., \& Beamish, P. W. (2003). Geographic scope and multinational enterprise performance. Strategic Management Journal, 24(13), 1289-1306. 
Goerzen, A., Beamish, P. W. (2005). The effect of alliance network diversity on multinational enterprise performance. Strategic Management Journal, 26(4), 333-354.

Gomez-Mejia, L. R., \& Palich, L. E. (1997). Cultural diversity and the performance of multinational firms. Journal of International Business Studies, 28(2), 309-335.

Grant, R. M., Jammine, A. P., \& Thomas, H. (1988). Diversity, diversification, and profitability among British manufacturing companies, 1972-1984. Academy of Management Journal, 31(4), 771-801.

Grimsey, D., \& Lewis, M. (2007). Public private partnerships: The worldwide revolution in infrastructure provision and project finance. Cheltenham: Edward Elgar Publishing.

Guillén, M. F., \& García-Canal, E. (2007). La expansión internacional de la empresa española: una nueva base de datos sistemática. Información Comercial Española, ICE: Revista de Economía. Revista de Economía, 839, 23-34.

Guillén, M. F., \& García-Canal, E. (2010). The New Multinationals. Spanish firms in a global context. Cambridge: Cambridge University Press.

Gupta, V., Hanges, P. J., \& Dorfman, P. (2002). Cultural clusters: Methodology and findings. Journal of World Business, 37(1), 11-15.

Guthrie, G. (2006). Regulating infrastructure: The impact on risk and investment. Journal of Economic Literature, 44(4), 925-972.

Heckman, J. J. (1979). Sample selection bias as a specification error. Econometrica, 47(1), 153-161.

Henisz, W. J. (2002). The institutional environment for infrastructure investment. Industrial and Corporate Change, 11(2), 355-389.

Henisz, W. J. (2003). The power of the Buckley and Casson thesis: The ability to manage institutional idiosyncrasies. Journal of International Business Studies, 34(2), 173-184.

Hennart, J.-F. (2007). The theoretical rationale for a multinationality-performance relationship. Management International Review, 47(3), 423-452.

Hitt, M. A., Ahlstrom, D., Dacin, M. T., Levitas, E., \& Svobodina, L. (2004). The institutional effects on strategic alliance partner selection in transition economies: China vs. Russia. Organization Science, 15(2), 173-185.

Hitt, M. A., Hoskisson, R. E., \& Kim, H. (1997). International diversification: Effects on innovation and firm performance in product-diversified firms. Academy of Management Journal, 40(4), 767-798.

Hofstede, G., \& Bond, M. H. (1988). The Confucius connection: From cultural roots to economic growth. Organizational Dynamics, 16(4), 5-21.

Holmes Jr, R. M., Miller, T., Hitt, M. A., \& Salmador, M. P. (2013). The interrelationships among informal institutions, formal institutions, and inward foreign direct investment. Journal of Management, 39(2), 531-566.

Hymer, S. H. (1976). The international operations of national firms: A study of direct foreign investment. Cambridge: MIT Press.

Jackson, G., \& Deeg, R. (2008). Comparing capitalisms: Understanding institutional diversity and its implications for international business. Journal of International Business Studies, 39(4), 540-561.

Javalgi, R. G., Hall, K. D., \& Cavusgil, S. T. (2014). Corporate entrepreneurship, customer-oriented selling, absorptive capacity, and international sales performance in the international B2B setting: 
Conceptual framework and research propositions. International Business Review, 23(6), 11931202.

Kaasa, A., Vadi, M., \& Varblane, U. (2014). Regional cultural differences within European countries: evidence from multi-country surveys. Management International Review, 54(6), 825-852.

Keim, G. D., \& Hillman, A. J. (2008). Political environments and business strategy: Implications for managers. Business Horizons, 51(1), 47-53.

Kim, H., Hoskisson, R. E., \& Lee, S. H. (2015). Why strategic factor markets matter: "New" multinationals' geographic diversification and firm profitability. Strategic Management Journal, 36(4), 518-536.

Kim, J. U., \& Aguilera, R. V. (2015). The world is spiky: An internationalization framework for a semi-globalized world. Global Strategy Journal, 5(2), 113-132.

Kirkpatrick, C., Parker, D., Zhang, Y. (2006). Foreign direct investment in infrastructure in developing countries: Does regulation make a difference? Transnational Corporations, 15(1), 143-171.

Kogut, B. (1985). Designing global strategies: Comparative and competitive value-added chains. Sloan Management Review, 26(4), 15-28.

Konara, P., \& Shirodkar, V. (2018). Regulatory institutional distance and MNCs' subsidiary performance: climbing up vs. climbing down the institutional ladder. Journal of International Management, 24(4), 333-347.

Kostova, T. (1999). Transnational transfer of strategic organizational practices: A contextual perspective. Academy of Management Review, 24(2), 308-324.

Kostova, T., \& Roth, K. (2002). Adoption of an organizational practice by subsidiaries of multinational corporations: Institutional and relational effects. Academy of Management Journal, 45(1), 215233.

Kostova, T., \& Zaheer, S. (1999). Organizational legitimacy under conditions of complexity: The case of the multinational enterprise. Academy of Management Review, 24(1), 64-81.

Kostova, T., Nell, P. C., \& Hoenen, A. K. (2018). Understanding agency problems in headquarterssubsidiary relationships in multinational corporations: a contextualized model. Journal of Management, 44(7): 2611-2637.

Kutner, M. H., Nachtsheim, C. J., Neter, J., \& Li, W. (2004). Applied linear regression models. New York: McGraw-Hill/Irwin.

La Porta, R., Lopez-de-Silanes, F., Pop-Eleches, C., \& Shleifer, A. (2004). Judicial checks and balances. Journal of Political Economy, 112(2), 445-470.

La Porta, R., Lopez-de-Silanes, F., Shleifer, A., \& Vishny, R. W. (1998). Law and finance. Journal of Political Economy, 106(6), 1113-1155.

Lemmon, M. L., \& Lins, K. V. (2003). Ownership structure, corporate governance, and firm value: Evidence from the East Asian financial crisis. The Journal of Finance, 58(4), 1445-1468.

Liou, R. S., \& Rao-Nicholson, R. (2019). Age Matters: The Contingency of Economic Distance and Economic Freedom in Emerging Market Firm's Cross-Border M\&A Performance. Management International Review, 59(3), 355-386.

Lu, J. W., \& Beamish, P. W. (2001). The internationalization and performance of SMEs. Strategic Management Journal, 22(6-7), 565-586. 
Lu, J. W., \& Beamish, P. W. (2004). International diversification and firm performance: The S-curve hypothesis. Academy of Management Journal, 47(4), 598-609.

Luo, Y., \& Peng, M. W. (1999). Learning to compete in a transition economy: Experience, environment, and performance. Journal of International Business Studies, 30(2), 269-295.

Madhok, A. (1997). Cost, value and foreign market entry mode: The transaction and the firm. Strategic Management Journal, 18(1), 39-61.

Makino, S., Isobe, T., \& Chan, C. M. (2004). Does country matter? Strategic Management Journal, 25(10), 1027-1043.

Mallon, M. R., \& Fainshmidt, S. (2017). Assets of foreignness: A theoretical integration and agenda for future research. Journal of International Management, 23(1), 43-55.

Mendoza, X., Espinosa-Méndez, C., \& Araya-Castillo, L. (in press). When geography matters: International diversification and firm performance of Spanish multinationals. BRQ Business Research Quarterly. Available online 5 January 2019.

Meyer, K. E., \& Tran, Y. T. T. (2006). Market penetration and acquisition strategies for emerging economies. Long Range Planning, 39(2), 177-197.

Michel, A., \& Shaked, I. (1986). Multinational corporations vs. domestic corporations: Financial performance and characteristics. Journal of International Business Studies, 17(3), 89-100.

Miller, S. R., Lavie, D., \& Delios, A. (2016). International intensity, diversity, and distance: Unpacking the internationalization-performance relationship. International Business Review, 25(4), 907-920.

Morosini, P., Shane, S., \& Singh, H. (1998). National cultural distance and cross-border acquisition performance. Journal of International Business Studies, 29(1), 137-158.

Moschieri, C., Ragozzino, R., \& Campa, J. M. (2014). Does regional integration change the effects of country-level institutional barriers on M\&A? The case of the European Union. Management International Review, 54(6), 853-877.

Nguyen, Q.T. (2017). Multinationality and performance literature: A critical review and future research agenda. Management International Review, 57, 311-347.

North, D. C. (1990). A transaction cost theory of politics. Journal of Theoretical Politics, 2(4), 355-367.

North, D. C. (1991). Institutions. Journal of Economic Perspectives, 5(1), 97-112.

Oh, C. H., \& Contractor, F. (2014). A regional perspective on multinational expansion strategies: Reconsidering the three-stage paradigm. British Journal of Management, 25(S1), S42-S59.

Oh, C. H., \& Li, J. (2015). Commentary: Alan Rugman and the theory of the regional multinationals. Journal of World Business, 50(4), 631-633.

Oh, C. H., Sohl, T., \& Rugman, A. M. (2015). Regional and product diversification and the performance of retail multinationals. Journal of International Management, 21(3), 220-234.

Osegowitsch, T., \& Sammartino, A. (2008). Reassessing (home-) regionalisation. Journal of International Business Studies, 39(2), 184-196.

Parker, D. (2003). Performance, risk and strategy in privatised, regulated industries: The UK's experience. International Journal of Public Sector Management, 16(1), 75-100.

Peng, M. W. (2002). Towards an institution-based view of business strategy. Asia Pacific Journal of Management, 19(2-3), 251-267. 
Peng, M. W., Sun, S. L., Pinkham, B., \& Chen, H. (2009). The institution-based view as a third leg for a strategy tripod. Academy of Management Perspectives, 23(3), 63-81.

Peng, M. W., Wang, D. Y., \& Jiang, Y. (2008). An institution-based view of international business strategy: A focus on emerging economies. Journal of International Business Studies, 39(5), 920936.

Picone, P. M., Dagnino, G. B., \& Minà, A. (2014). The origin of failure: A multidisciplinary appraisal of the hubris hypothesis and proposed research agenda. Academy of Management Perspectives, 28(4), 447-468.

Qian, G., Khoury, T. A., Peng, M. W., \& Qian, Z. (2010). The performance implications of intra-and inter-regional geographic diversification. Strategic Management Journal, 31(9), 1018-1030.

Qian, G., Li, L., \& Rugman, A. M. (2013). Liability of country foreignness and liability of regional foreignness: Their effects on geographic diversification and firm performance. Journal of International Business Studies, 44(6), 635-647.

Ral-Trebacz, A., Eckert, S., \& Dittfeld, M. (2018). The value of internationalization: Disentangling the interrelationship between regionalization strategies, firm-specific assets related to marketing and performance. Multinational Business Review, 26(1), 71-90.

Ramamurti, R. (2003). Can governments make credible promises? Insights from infrastructure projects in emerging economies. Journal of International Management, 9(3), 253-269.

Ramamurti, R., \& Doh, J. P. (2004). Rethinking foreign infrastructure investment in developing countries. Journal of World Business, 39(2), 151-167.

Rangan, S., \& Sengul, M. (2009). The influence of macro structure on the foreign market performance of transnational firms: The value of IGO connections, export dependence, and immigration links. Administrative Science Quarterly, 54(2), 229-267.

Riahi-Belkaoui, A. (1998). The effects of the degree of internationalization on firm performance. International Business Review, 7(3), 315-321.

Ronen, S., \& Shenkar, O. (2013). Mapping world cultures: Cluster formation, sources and implications. Journal of International Business Studies, 44(9), 867-897.

Rugman, A. M. (2003). Regional strategy and the demise of globalization. Journal of International Management, 9(4), 409-417.

Rugman, A. M., \& Verbeke, A. (2004). A perspective on regional and global strategies of multinational enterprises. Journal of International Business Studies, 35(1), 3-18.

Rugman, A. M., \& Verbeke, A. (2007). Liabilities of regional foreignness and the use of firm-level versus country-level data: A response to Dunning et al. (2007). Journal of International Business Studies, $38(1), 200-205$.

Rugman, A. M., \& Verbeke, A. (2008). A new perspective on the regional and global strategies of multinational services firms. Management International Review, 48(4), 397-411.

Ruigrok, W., Amann, W., \& Wagner H. (2007). The internationalization-performance relationship at Swiss firms: A test of the S-shape and extreme degrees of internationalization. Management International Review, 47(3), 349-368.

Rumelt, R. P. (2011). Good strategy/bad strategy: The difference and why it matters. New York: Crown Business. 
Sawant, R. J. (2010). The economics of large-scale infrastructure FDI: The case of project finance. Journal of International Business Studies, 41(6), 1036-1055.

Shirodkar, V., \& Konara, P. (2017). Institutional distance and foreign subsidiary performance in emerging markets: Moderating effects of ownership strategy and host-country experience. Management International Review, 57(2), 179-207.

Tallman, S., \& Li, J. (1996). Effects of international diversity and product diversity on the performance of multinational firms. Academy of Management Journal, 39(1), 179-196.

Taras, V., Steel, P., \& Kirkman, B. L. (2016). Does country equate with culture? Beyond geography in the search for cultural boundaries. Management International Review, 56(4), 455-487.

Thomas, D. E., \& Eden, L. (2004). What is the shape of the multinationality-performance relationship? Multinational Business Review, 12(1), 89-110.

Verbeke, A., \& Asmussen, C. G. (2016). Global, local, or regional? The locus of MNE strategies. Journal of Management Studies, 53(6), 1051-1075.

Verbeke, A., \& Forootan, M. Z. (2012). How good are multinationality-performance (M-P) empirical studies? Global Strategy Journal, 2(4), 332-344.

Verbeke, A., Kano, L., \& Yuan, W. (2016). Inside the regional multinationals: A new value chain perspective on subsidiary capabilities. International Business Review, 25(3), 785-793.

Vergés, J. (1999). Balance de las políticas de privatización de empresas públicas en España, 1985-1999. Economía Industrial, 330, 121-139.

Vergés, J. (2010). Privatización de empresas públicas y liberalización. Working paper.

Vernon, R. (1971). Sovereignty at bay: The multinational spread of U.S. enterprises. New York: Basic Books.

Villalonga, B. (2004). Intangible resources, Tobin's q, and sustainability of performance differences. Journal of Economic Behavior \& Organization, 54(2), 205-230.

Wan, W. P., \& Hoskisson, R. E. (2003). Home country environments, corporate diversification strategies and firm performance. Academy of Management Journal, 46(1), 27-45.

Wiersema, M. F., \& Bowen, H. P. (2011). The relationship between international diversification and firm performance: why it remains a puzzle. Global Strategy Journal, 1(1-2), 152-170.

Wu, Z., \& Salomon, R. (2016). Does imitation reduce the liability of foreignness? Linking distance, isomorphism, and performance. Strategic Management Journal, 37(12), 2441-2462.

Zaheer, S. (1995). Overcoming the liability of foreignness. Academy of Management Journal, 38(2), 341363.

Zhou, N., \& Guillén, M. F. (2015). From home country to home base: A dynamic approach to the liability of foreignness. Strategic Management Journal, 36(6), 907-917.

Zhou, N., \& Guillén, M. F. (2016). Categorizing the liability of foreignness: Ownership, location, and internalization-specific dimensions. Global Strategy Journal, 6(4), 309-329. 
Table 1 Firm-year observations and description of international presence and international dispersion by industry

\begin{tabular}{|c|c|c|c|c|c|c|c|c|c|c|c|c|}
\hline \multirow{2}{*}{ Industry } & \multicolumn{2}{|c|}{$\begin{array}{l}\text { Firm-year } \\
\text { observations }\end{array}$} & \multicolumn{2}{|c|}{$\begin{array}{c}\text { Number of foreign } \\
\text { operations }\end{array}$} & \multicolumn{2}{|c|}{$\begin{array}{c}\text { Number of } \\
\text { foreign countries }\end{array}$} & \multicolumn{2}{|c|}{$\begin{array}{c}\text { Intercultural } \\
\text { dispersion }\end{array}$} & \multicolumn{2}{|c|}{$\begin{array}{c}\text { Interregulatory } \\
\text { dispersion }\end{array}$} & \multicolumn{2}{|c|}{$\begin{array}{l}\text { Interregional } \\
\text { dispersion }\end{array}$} \\
\hline & Domestic & Multinationals & Mean & Std. Dev. & Mean & Std. Dev. & Mean & Std. Dev. & Mean & Std. Dev. & Mean & Std. Dev. \\
\hline Infrastructure industries & 71 & 211 & 38.91 & 37.32 & 16.07 & 11.27 & 4.31 & 2.24 & 1.59 & 1.12 & 1.96 & 0.78 \\
\hline Energy and water & 37 & 120 & 30.68 & 26.49 & 12.71 & 8.72 & 3.78 & 1.78 & 1.44 & 1.07 & 1.91 & 0.73 \\
\hline Transportation and telecommunications & 26 & 30 & 51.67 & 51.38 & 15.96 & 10.69 & 4.48 & 2.56 & 1.15 & 1.13 & 1.59 & 0.75 \\
\hline Construction & 8 & 61 & 48.89 & 43.68 & 22.65 & 13.09 & 5.25 & 2.57 & 2.11 & 1.05 & 2.25 & 0.81 \\
\hline Non-infrastructure industries & 347 & 550 & 8.24 & 8.86 & 5.51 & 5.17 & 2.32 & 1.67 & 1.06 & 0.86 & 1.35 & 1.03 \\
\hline Other soft services & 119 & 58 & 7.16 & 7.30 & 3.86 & 3.17 & 1.34 & 1.47 & 0.96 & 1.07 & 0.46 & 0.54 \\
\hline Other hard services & 3 & 98 & 11.48 & 11.45 & 7.96 & 6.80 & 2.77 & 1.62 & 0.97 & 0.92 & 1.41 & 0.92 \\
\hline Food and drink & 40 & 82 & 15.78 & 11.75 & 10.35 & 6.81 & 3.47 & 1.80 & 1.39 & 0.96 & 2.10 & 1.06 \\
\hline Iron and steel & 65 & 44 & 8.76 & 4.78 & 5.41 & 2.69 & 2.76 & 1.83 & 1.32 & 0.82 & 1.54 & 1.12 \\
\hline Machinery and equipment & 36 & 54 & 7.27 & 5.66 & 4.63 & 2.32 & 2.78 & 1.07 & 1.43 & 0.71 & 1.67 & 1.31 \\
\hline Building materials & 45 & 54 & 5.33 & 4.08 & 3.48 & 2.06 & 1.76 & 1.36 & 0.83 & 0.62 & 1.19 & 0.55 \\
\hline Chemical products and medical equipment & 9 & 122 & 3.86 & 3.84 & 3.00 & 2.18 & 1.75 & 1.43 & 0.84 & 0.68 & 1.16 & 0.88 \\
\hline Stationery and office supplies & 30 & 38 & 2.59 & 1.27 & 2.41 & 0.98 & 1.34 & 0.90 & 0.84 & 0.63 & 0.97 & 0.74 \\
\hline All industries (overall sample) & 418 & 761 & 16.92 & 25.30 & 8.50 & 8.81 & 2.89 & 2.05 & 1.21 & 0.97 & 1.53 & 1.00 \\
\hline
\end{tabular}


Table 2 Heckman's second-stage descriptive statistics and correlation matrix

\begin{tabular}{|c|c|c|c|c|c|c|c|c|c|c|c|c|c|c|c|c|c|c|c|c|c|}
\hline & & Mean & S.D. & 1 & 2 & 3 & 4 & 5 & 6 & 7 & 8 & 9 & 10 & 11 & 12 & 13 & 14 & 15 & 16 & 17 & 18 \\
\hline 1 & Profitability & 7.26 & 7.89 & 1.00 & & & & & & & & & & & & & & & & & \\
\hline 2 & Intercultural dispersion & 2.89 & 2.05 & -0.08 & 1.00 & & & & & & & & & & & & & & & & \\
\hline 3 & Interregulatory dispersion & 1.21 & 0.97 & -0.11 & 0.75 & 1.00 & & & & & & & & & & & & & & & \\
\hline 4 & Interregional dispersion & 1.53 & 1.00 & -0.07 & 0.78 & 0.63 & 1.00 & & & & & & & & & & & & & & \\
\hline 5 & Infrastructure industries & 0.28 & 0.45 & 0.05 & 0.44 & 0.25 & 0.27 & 1.00 & & & & & & & & & & & & & \\
\hline 6 & Size & 2.40 & 5.62 & 0.07 & 0.47 & 0.28 & 0.28 & 0.54 & 1.00 & & & & & & & & & & & & \\
\hline 7 & Proprietary technology & 36.49 & 69.46 & -0.03 & 0.23 & 0.17 & 0.10 & 0.16 & 0.45 & 1.00 & & & & & & & & & & & \\
\hline 8 & Leverage & 0.14 & 0.12 & -0.09 & 0.11 & 0.06 & 0.02 & 0.30 & 0.26 & 0.04 & 1.00 & & & & & & & & & & \\
\hline 9 & Liquidity & 0.41 & 4.25 & -0.04 & -0.05 & -0.02 & -0.07 & -0.04 & -0.02 & -0.03 & -0.00 & 1.00 & & & & & & & & & \\
\hline 10 & Operating margin & 11.17 & 16.90 & 0.38 & -0.10 & -0.15 & -0.14 & 0.21 & 0.06 & -0.05 & 0.20 & -0.01 & 1.00 & & & & & & & & \\
\hline 11 & Family ownership & 9.13 & 18.25 & 0.08 & 0.04 & 0.01 & 0.09 & -0.02 & -0.11 & -0.15 & -0.10 & -0.02 & -0.04 & 1.00 & & & & & & & \\
\hline 12 & Board ownership & 15.99 & 21.92 & -0.08 & -0.08 & -0.11 & 0.00 & -0.23 & -0.18 & -0.06 & -0.02 & -0.03 & -0.07 & 0.10 & 1.00 & & & & & & \\
\hline 13 & State ownership & 3.24 & 13.87 & 0.02 & 0.05 & -0.01 & 0.03 & 0.13 & 0.07 & 0.02 & 0.03 & -0.02 & 0.02 & -0.12 & 0.14 & 1.00 & & & & & \\
\hline 14 & CEO duality & 0.31 & 0.46 & -0.03 & 0.01 & -0.08 & 0.01 & 0.00 & 0.07 & 0.09 & -0.21 & -0.04 & -0.10 & -0.12 & -0.07 & 0.08 & 1.00 & & & & \\
\hline 15 & Firm age & 69.40 & 37.79 & -0.02 & -0.08 & -0.11 & -0.04 & 0.22 & 0.09 & 0.10 & 0.17 & -0.05 & 0.03 & -0.18 & 0.03 & -0.04 & -0.03 & 1.00 & & & \\
\hline 16 & International experience & 14.62 & 10.57 & -0.02 & 0.39 & 0.26 & 0.31 & 0.09 & 0.26 & 0.03 & -0.11 & -0.04 & -0.14 & -0.06 & -0.03 & -0.07 & -0.03 & -0.02 & 1.00 & & \\
\hline 17 & WOS (\%) & 47.92 & 33.32 & -0.22 & -0.04 & 0.04 & -0.11 & -0.37 & -0.22 & 0.04 & -0.19 & -0.06 & -0.30 & 0.11 & 0.19 & -0.16 & 0.07 & -0.07 & 0.06 & 1.00 & \\
\hline 18 & Inverse Mills ratio & 0.54 & 1.37 & -0.14 & -0.24 & -0.13 & -0.23 & -0.20 & -0.15 & -0.19 & 0.02 & -0.02 & 0.01 & 0.01 & -0.06 & -0.06 & 0.02 & -0.26 & -0.10 & -0.02 & 1.00 \\
\hline
\end{tabular}


Table 3 Internationalization decision (robust panel-data probit) ${ }^{\mathrm{a}}$

\begin{tabular}{lc}
\hline & $\begin{array}{c}\text { Internationalization } \\
\text { decision }\end{array}$ \\
\hline Size & $2.462^{*}$ \\
& $(0.090)$ \\
Proprietary technology & $0.130^{* * *}$ \\
& $(0.005)$ \\
Leverage & $-3.139^{* *}$ \\
& $(0.034)$ \\
Liquidity & $-0.027^{* * *}$ \\
& $(0.000)$ \\
Operating margin & 0.000 \\
& $(0.757)$ \\
Accumulated mergers & $4.581^{*}$ \\
& $(0.068)$ \\
Firm age & 0.024 \\
& $(0.355)$ \\
Family ownership & 0.053 \\
Board ownership & $(0.106)$ \\
& -0.010 \\
State ownership & $(0.375)$ \\
CEO duality & -0.025 \\
& $(0.522)$ \\
Global mimetic behavior & -0.304 \\
Infrastructure industries & $(0.534)$ \\
Year control & $0.054^{* *}$ \\
Constant & $(0.012)$ \\
Industry dummies & -1.679 \\
Wald chi-sq & $(0.597)$ \\
Observations & $0.356^{* * *}$ \\
Number of firms & $(0.007)$ \\
& $-9.225^{* * *}$ \\
& $(0.000)$ \\
& Included \\
& $127.08^{* * *}$ \\
& $(0.000)$ \\
& 1,179 \\
& 103 \\
\hline
\end{tabular}

Robust pval in parentheses $* * * \mathrm{p}<0.01, * * \mathrm{p}<0.05, * \mathrm{p}<0.1$

${ }^{a}$ This table features the first stage of our Heckman analysis. The dependent variable is the internationalization decision (dummy taking the value of one if the firm had invested abroad from 1986 to the end of year t, and zero otherwise). There are 1,179 observations of 103 firms across a 22year period (1986-2007). We included robust standard errors to account for heteroskedasticity. 
Table 4 International dispersion and profitability (robust random-effects regressions) ${ }^{\mathrm{a}}$

\begin{tabular}{|c|c|c|c|}
\hline VARIABLES & Model I & Model II & Model III \\
\hline Intercultural dispersion & $\begin{array}{c}-0.773 * * \\
(0.029)\end{array}$ & & \\
\hline Interregulatory dispersion & & $\begin{array}{c}-1.499 * * \\
(0.023)\end{array}$ & \\
\hline Interregional dispersion & & & $\begin{array}{l}-1.154 * \\
(0.051)\end{array}$ \\
\hline Infrastructure industries & $\begin{array}{c}0.357 \\
(0.896)\end{array}$ & $\begin{array}{l}-0.104 \\
(0.969)\end{array}$ & $\begin{array}{l}-0.873 \\
(0.754)\end{array}$ \\
\hline Intercultural dispersion $\mathrm{x}$ Infrastructure industries & $\begin{array}{c}0.729 * * \\
(0.029)\end{array}$ & & \\
\hline Interregulatory dispersion $\mathrm{x}$ Infrastructure industries & & $\begin{array}{c}1.483 * * \\
(0.027)\end{array}$ & \\
\hline Interregional dispersion $\mathrm{x}$ Infrastructure industries & & & $\begin{array}{c}1.589 * * * \\
(0.004)\end{array}$ \\
\hline Size & $\begin{array}{c}0.139 \\
(0.127)\end{array}$ & $\begin{array}{c}0.143 \\
(0.110)\end{array}$ & $\begin{array}{c}0.128 \\
(0.152)\end{array}$ \\
\hline Proprietary technology & $\begin{array}{c}-0.033^{* *} \\
(0.044)\end{array}$ & $\begin{array}{c}-0.035^{* *} \\
(0.039)\end{array}$ & $\begin{array}{c}-0.030^{* *} * \\
(0.048)\end{array}$ \\
\hline Leverage & $\begin{array}{c}-5.875 \\
(0.150)\end{array}$ & $\begin{array}{l}-5.583 \\
(0.169)\end{array}$ & $\begin{array}{l}-6.111 \\
(0.139)\end{array}$ \\
\hline Liquidity & $\begin{array}{c}-0.008 \\
(0.634)\end{array}$ & $\begin{array}{l}-0.008 \\
(0.640)\end{array}$ & $\begin{array}{l}-0.023 \\
(0.219)\end{array}$ \\
\hline Operating margin & $\begin{array}{c}0.184 * * * \\
(0.000)\end{array}$ & $\begin{array}{c}0.185^{* * * *} \\
(0.000)\end{array}$ & $\begin{array}{c}0.186 * * * \\
(0.000)\end{array}$ \\
\hline Family ownership & $\begin{array}{c}0.019 \\
(0.256)\end{array}$ & $\begin{array}{c}0.015 \\
(0.358)\end{array}$ & $\begin{array}{c}0.017 \\
(0.330)\end{array}$ \\
\hline Board ownership & $\begin{array}{l}-0.014 \\
(0.526)\end{array}$ & $\begin{array}{l}-0.016 \\
(0.473)\end{array}$ & $\begin{array}{l}-0.016 \\
(0.470)\end{array}$ \\
\hline State ownership & $\begin{array}{l}-0.000 \\
(0.999)\end{array}$ & $\begin{array}{c}0.001 \\
(0.958)\end{array}$ & $\begin{array}{l}-0.001 \\
(0.960)\end{array}$ \\
\hline CEO duality & $\begin{array}{c}0.737 \\
(0.420)\end{array}$ & $\begin{array}{c}0.827 \\
(0.368)\end{array}$ & $\begin{array}{c}0.789 \\
(0.429)\end{array}$ \\
\hline Firm age & $\begin{array}{l}-0.000 \\
(0.996)\end{array}$ & $\begin{array}{l}-0.002 \\
(0.925)\end{array}$ & $\begin{array}{c}0.000 \\
(0.991)\end{array}$ \\
\hline International experience & $\begin{array}{c}0.064 \\
(0.201)\end{array}$ & $\begin{array}{c}0.058 \\
(0.214)\end{array}$ & $\begin{array}{c}0.049 \\
(0.299)\end{array}$ \\
\hline WOS $(\%)$ & $\begin{array}{c}0.018 \\
(0.250)\end{array}$ & $\begin{array}{c}0.018 \\
(0.268)\end{array}$ & $\begin{array}{c}0.017 \\
(0.244)\end{array}$ \\
\hline Inverse Mills ratio & $\begin{array}{c}-0.866^{* *} \\
(0.015)\end{array}$ & $\begin{array}{c}-0.819 * * \\
(0.024)\end{array}$ & $\begin{array}{c}-0.917 * * * \\
(0.010)\end{array}$ \\
\hline Constant & $\begin{array}{c}3.233 \\
(0.113)\end{array}$ & $\begin{array}{l}3.673^{*} \\
(0.092)\end{array}$ & $\begin{array}{c}4.143 * * \\
(0.036)\end{array}$ \\
\hline Industry dummies & Included & Included & Included \\
\hline Year dummies & Included & Included & Included \\
\hline Wald chi-sq & $669.29 * * *$ & $815.04 * * *$ & $722.16^{* * *}$ \\
\hline
\end{tabular}


$(0.000) \quad(0.000)$

$(0.000)$

Observations

Number of firms

\begin{tabular}{rrr}
689 & 689 & 689 \\
62 & 62 & 62 \\
\hline
\end{tabular}

Robust pval in parentheses
$* * * \mathrm{p}<0.01, * * \mathrm{p}<0.05, * \mathrm{p}<0.1$

${ }^{a}$ This table features the second stage of our Heckman analysis. The dependent variable is profitability $\left(R O A_{t-1, t, t+1}\right)$. There are 689 observations of 62 firms across a 22-year period (1986-2007). The number of firms diminishes from the first stage because we only consider the observations of multinational firms. We entered the inverse Mills ratio calculated from the first stage to control for potential endogeneity issues. We included robust standard errors to account for heteroskedasticity.

Table 5 International dispersion and profitability (CAGE factor) ${ }^{\mathrm{a}}$

VARIABLES

CAGE factor

$-1.309 *$

(0.077)

Infrastructure industries

1.200

(0.655)

CAGE factor $\mathrm{x}$ Infrastructure industries

$1.739 * * *$

(0.008)

Size

0.136

(0.150)

Proprietary technology

$-0.029 *$

(0.069)

Leverage

$-6.506$

$(0.137)$

Liquidity

$-0.038 *$

(0.079)

Operating margin

$0.183^{* * *}$

Family ownership

(0.000)

0.021

$(0.218)$

Board ownership

$-0.016$

$(0.520)$

State ownership

$-0.002$

CEO duality

1.247

(0.233)

Firm age

$-0.006$

(0.792)

International experience

0.061

(0.210) 
WOS $(\%)$

0.002

(0.899)

Inverse Mills ratio

$-0.813 * *$

(0.019)

Constant

1.243

(0.717)

Industry dummies

Included

Year dummies

Included

Wald chi-sq

$718.67 * * *$

(0.000)

Observations

650

Number of firms

61

${ }^{a}$ This table features the additional test in which we replaced each dimension of international dispersion in the second stage of our Heckman analysis by a factor containing the dimensions in Ghemawat's CAGE framework (2001). The dependent variable is profitability $\left(R O A_{t-1, t, t+1}\right)$.

Table 6 International dispersion and profitability (international dispersion factor) ${ }^{\mathrm{a}}$

\begin{tabular}{lc} 
VARIABLES & \\
\hline \multirow{2}{*}{ International dispersion factor } & $-1.689^{* *}$ \\
& $(0.014)$ \\
Infrastructure industries & 2.254 \\
& $(0.339)$ \\
International dispersion factor x Infrastructure industries & $1.655^{* *}$ \\
& $(0.010)$ \\
Size & 0.123 \\
& $(0.188)$ \\
Proprietary technology & $-0.032^{*}$ \\
& $(0.053)$ \\
Leverage & -5.963 \\
& $(0.139)$ \\
Liquidity & -0.013 \\
& $(0.416)$ \\
Operating margin & $0.184 * *$ \\
& $(0.000)$ \\
Family ownership & 0.018 \\
& $(0.284)$ \\
Board ownership & -0.015 \\
& $(0.487)$ \\
State ownership & -0.000
\end{tabular}




\begin{tabular}{|c|c|}
\hline & $(0.984)$ \\
\hline CEO duality & 0.744 \\
\hline Firm age & $\begin{array}{l}(0.429) \\
-0.002 \\
(0.929)\end{array}$ \\
\hline International experience & $\begin{array}{c}0.066 \\
(0.171)\end{array}$ \\
\hline WOS (\%) & $\begin{array}{c}0.019 \\
(0.226)\end{array}$ \\
\hline Inverse Mills ratio & $\begin{array}{c}-0.868 * * \\
(0.016)\end{array}$ \\
\hline Constant & $\begin{array}{c}1.411 \\
(0.451)\end{array}$ \\
\hline Industry dummies & Included \\
\hline Year dummies & Included \\
\hline Wald chi-sq & $\begin{array}{c}738.94 * * * \\
(0.000)\end{array}$ \\
\hline Observations & 689 \\
\hline Number of firms & 62 \\
\hline
\end{tabular}

${ }^{a}$ This table features the robustness test in which we replaced each dimension of international dispersion in the second stage of our Heckman analysis by an international dispersion factor. The dependent variable is profitability $\left(R_{0 A} O A_{t-1, t, t+1}\right)$.

Table 7 International dispersion and profitability (above-average international dispersion) ${ }^{\mathrm{a}}$

\section{VARIABLES}

Above-average international dispersion

$-0.973 * *$

$(0.011)$

Infrastructure industries

0.714

$(0.774)$

$0.985^{* *}$

Above-average international dispersion $\mathrm{x}$ Infrastructure industries

$(0.018)$

Size

$0.143^{*}$

$(0.098)$

Proprietary technology

$-0.033 * *$

$(0.037)$

Leverage

$-5.733$

$(0.160)$

Liquidity

$-0.008$

(0.598) 
Operating margin

Family ownership

Board ownership

State ownership

CEO duality

Firm age

International experience

WOS (\%)

Inverse Mills ratio

Constant

Industry and year dummies

Wald chi-sq

Observations

Number of firms
$0.186^{* * * *}$

$(0.000)$

0.017

$(0.304)$

$-0.014$

$(0.538)$

0.005

$(0.837)$

0.751

$(0.435)$

0.000

$(0.993)$

0.057

$(0.230)$

0.020

$(0.185)$

$-0.906 * *$

$(0.020)$

2.470

$(0.192)$

Included

$753.97 * * *$

$(0.000)$

689

Robust pval in parentheses

$* * * \mathrm{p}<0.01, * * \mathrm{p}<0.05, * \mathrm{p}<0.1$

${ }^{a}$ This table features the additional test in which we replaced each dimension of international dispersion in the second stage of our Heckman analysis by a measure containing the number of dimensions where the firm is more dispersed than the average of the sample. The dependent variable is

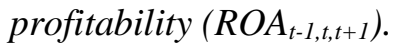


Figure 1. Impact of intercultural dispersion on profitability.



Figure 2. Impact of interregulatory dispersion on profitability.

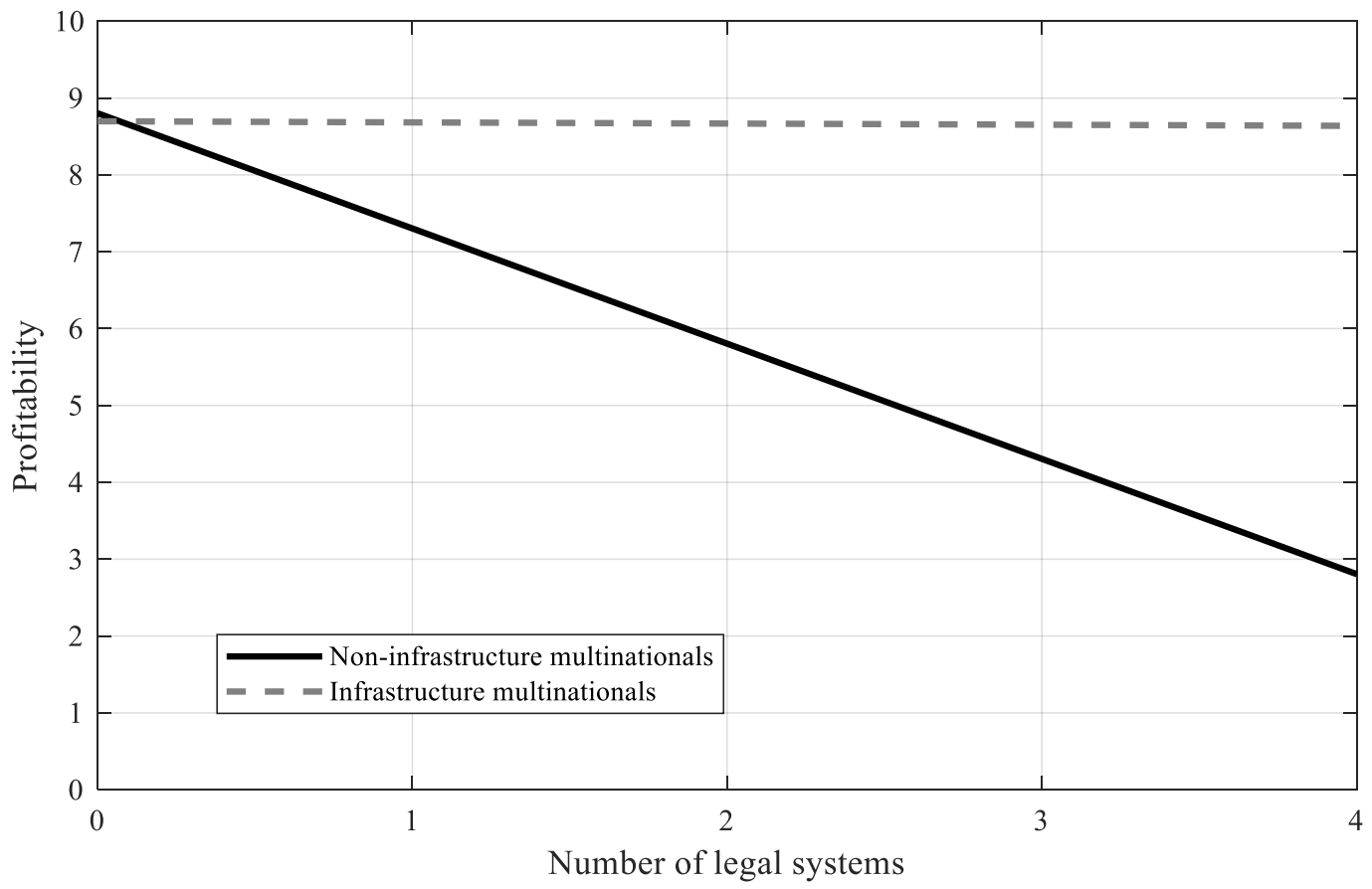


Figure 3. Impact of interregional dispersion on profitability.

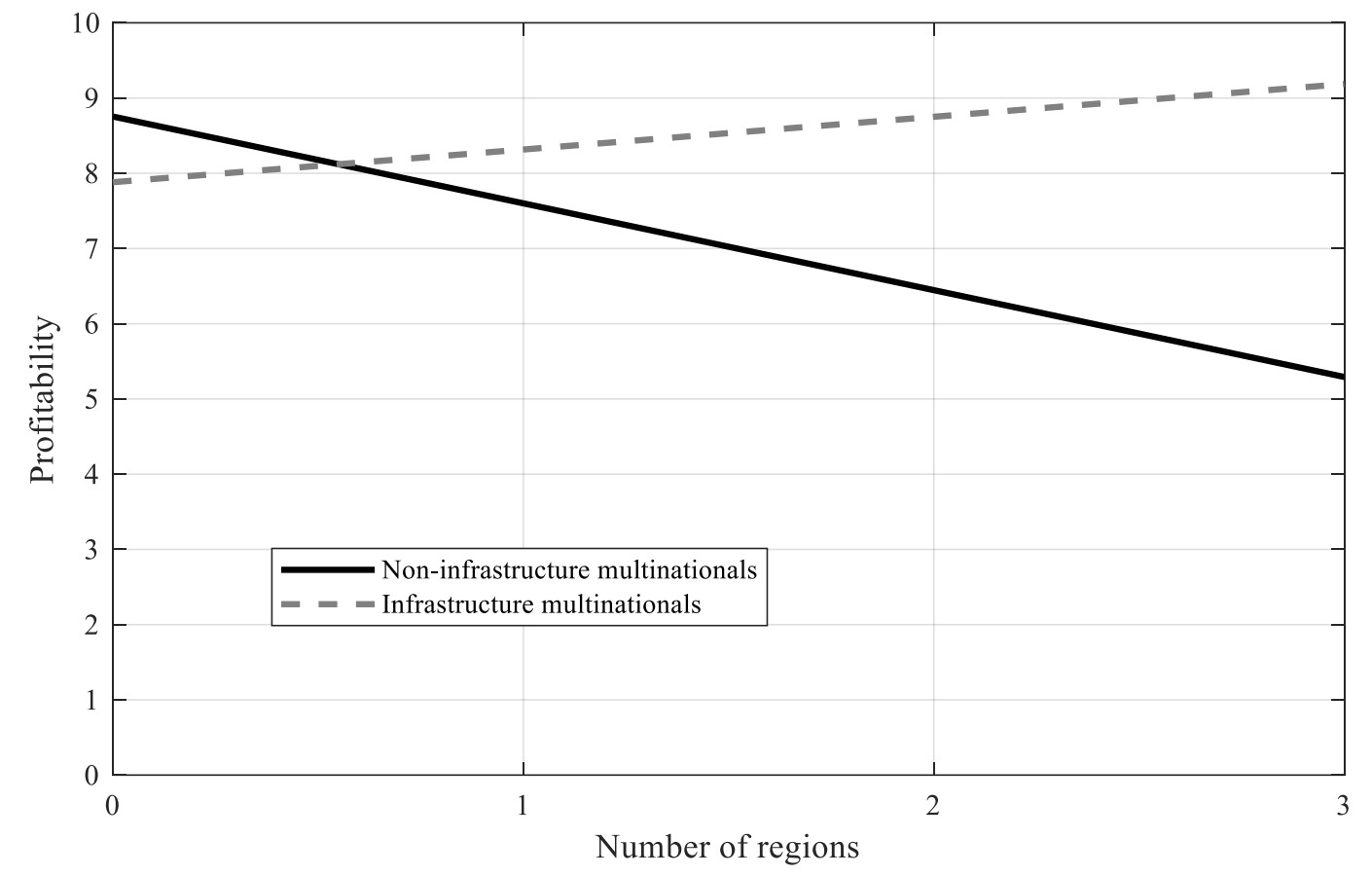

